University of San Diego

Digital USD

Theses

Theses and Dissertations

Summer 8-31-2017

\title{
Long-term changes in a spatially subsidized insular ecosystem in the archipelago of Bahía de los Ángeles, Baja California, Mexico
}

Thais Fournier

University of San Diego

Follow this and additional works at: https://digital.sandiego.edu/theses

Part of the Desert Ecology Commons, Marine Biology Commons, and the Terrestrial and Aquatic Ecology Commons

\section{Digital USD Citation}

Fournier, Thais, "Long-term changes in a spatially subsidized insular ecosystem in the archipelago of Bahía de los Ángeles, Baja California, Mexico" (2017). Theses. 24.

https://digital.sandiego.edu/theses/24

This Thesis: Open Access is brought to you for free and open access by the Theses and Dissertations at Digital USD. It has been accepted for inclusion in Theses by an authorized administrator of Digital USD. For more information, please contact digital@sandiego.edu. 


\section{UNIVERSITY OF SAN DIEGO}

\section{San Diego}

\section{Long - term changes in a spatially subsidized insular ecosystem in the archipelago of Bahía de los Ángeles, Baja California, Mexico}

A thesis submitted in partial satisfaction of the

requirements for the degree of

Master of Science in Marine Science

by

Thaïs M. Fournier

Thesis Committee

Drew Talley, Ph.D., Chair

Zhi-Yong Yin, Ph.D.

Theresa Sinicrope Talley, Ph.D.

Francisco Sánchez - Piñero, Ph.D. 
The thesis of Thaïs M. Fournier is approved by:

\begin{tabular}{c}
\hline $\begin{array}{c}\text { Drew Talley, Ph.D., Chair } \\
\text { University of San Diego }\end{array}$ \\
\hline Zhi-Yong Yin, Ph.D. \\
University of San Diego \\
\hline Theresa Sinicrope Talley, Ph.D. \\
University of California, San Diego \\
Francisco Sánchez - Piñero, Ph.D. \\
Universidad de Granada \\
University of San Diego
\end{tabular}

San Diego

2017 
Copyright 2017 Thaïs M. Fournier 


\section{DEDICATION}

"What physicists view as noise is music to the ecologist; the individuality of populations and communities is their most striking, intrinsic, and inspiring characteristic." - Simberloff

This thesis is dedicated to my family: Ana Maria Massa, Paul Leo Fournier, Tamarah Bacon, and Lauren Palmaccio. Thank you for always encouraging and supporting all my endeavors and dreams. I love you all so much. 


\section{ACKNOWLEDGMENTS}

I would first like to thank my committee chair, Dr. Drew Talley for being such an understanding individual and for his endless support, advice, and humor. Thank you to my committee members, Dr. John Yin, Dr. Theresa Sinicrope Talley, and Dr. Paco Sánchez-Piñero for training me to become a scientist and contributing endless hours of edits and advice. Thank you Mom for always telling me about the importance of getting an education and supporting me. Because of you, I have completed the American Dream. Dad, thank you for always supporting and encouraging my adventures, and making sure I took every opportunity to explore the world. Thank you to Joy Shapiro, Kate Hargenrader, Laura Schwebel, Elizabeth Johnson, and Nima Farchadi whose humor, positivity, and love helped me survive the long nights, doubts, and all the other hardships that come with completing a M.S. degree. I would like to thank all sources of funding for this project including, but not limited to: The University of San Diego, the National Science Foundation, and Ocean Discovery Institute. Thank you to all the volunteers that helped collect this data, including Earthwatch, Ocean Discovery Institute and various scientists and assistants; without your help we would not be able to explore this long-term dataset in this beautiful archipelago of Bahía de los Ángeles. Finally, I would like to thank Daniel J. Griffin for his encouragement and unconditional love during this time and always being my number one supporter. Murakoze umusheri wanyje. Ndagukunda. 
TABLE OF CONTENTS

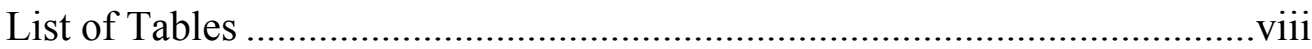

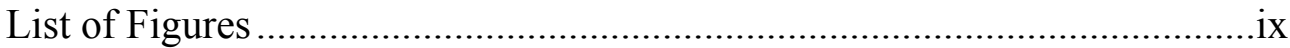

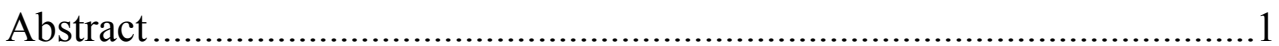

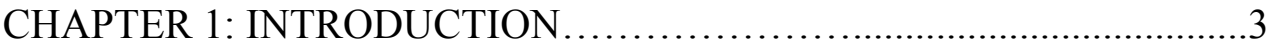

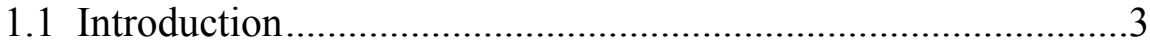

1.1.1 Community Responses to Spatial Subsidies ...............3

1.1.2 Spatial Subsidies: Shore Drift.....................................

1.1.3 Spatial Subsidies: Ornithogenic Influence..................6

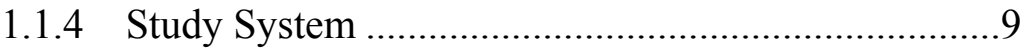

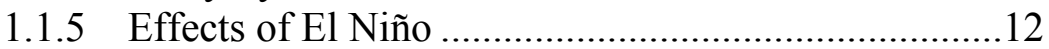

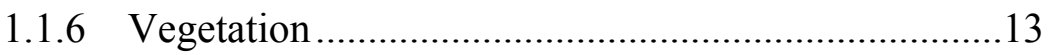

$1.1 .7 \quad$ Fauna........................................................................

1.1.8 Project Goal and Objectives........................................15

1.1.9 Statement of Hypotheses............................................17

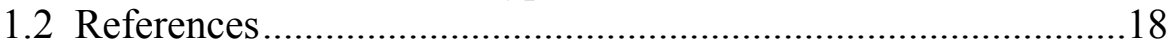

II. CHAPTER 2: LONG - TERM CHANGES IN A SPATIALLY SUBSIDIZED INSULAR ECOSYSTEM IN BAHÍA DE LOS ÁNGELES, BAJA CALIFORNIA,

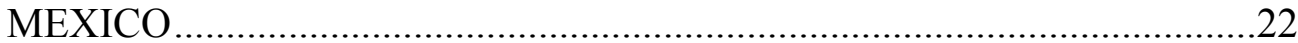

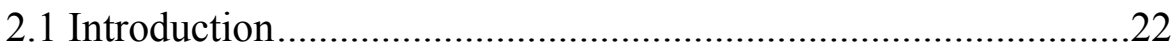

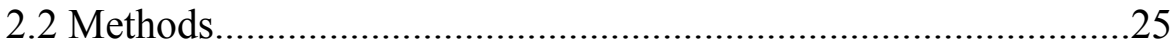

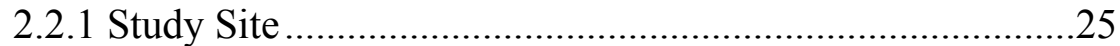

2.2.2 Field Techniques .........................................................29

2.2.2.1 Sampling of Tenebrionidae.....................................29

2.2.2.2 Plant Cover.................................................................

2.2.2.3 Ornithogenic Guano................................................30

2.2.2.4 Meteorological Data.................................................34

2.2.2.4.1 Precipitation ..................................................

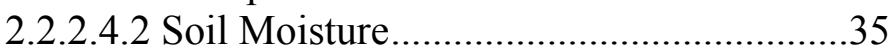

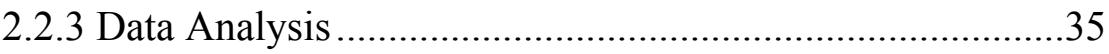

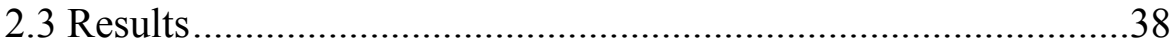

2.3.1 Precipitation ..................................................................

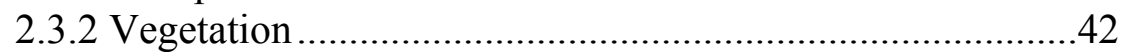

2.3.3 Tenebrionid Abundance..........................................................46

2.3.4 Tenebrionid Diversity .........................................................52

2.3.5 Tenebrionid Community Composition (TCC)....................55

2.3.5.1 TCC with Environmental Variables..........................58 


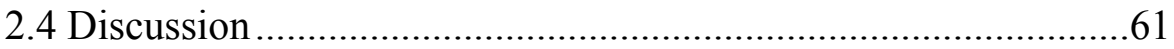

2.4.1 Effects of Precipitation .....................................................61

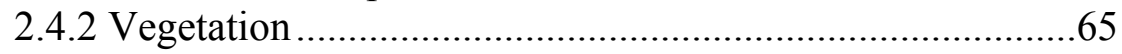

2.4.3 Tenebrionid Abundance........................................................66

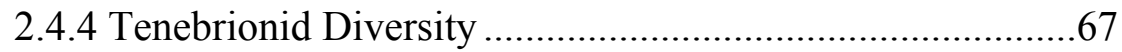

2.4.5 Tenebrionid Community Composition (TCC)....................67

\section{CHAPTER 3: CONCLUSIONS}

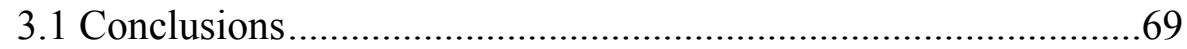

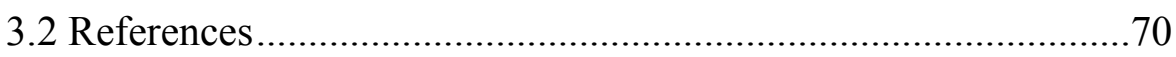

Appendix A Average Monthly Precipitation Data from 1996 - 2016 ..........74 Appendix B Average Monthly Temperature $\left(\mathrm{C}^{\circ}\right)$ Data from $1996-2012 \ldots 75$ Appendix C Monthly Soil Moisture from 1995 - 2016.................................76 


\section{LIST OF TABLES}

Table 2.1. Island physical characteristics of Bahía de los Ángeles...............32

Table 2.2. Univariate results from a multivariate GLM regression for the relationship between rain and plant cover on non - bird and bird islands.....43 Table 2.3. Univariate results from a multivariate GLM regression for the relationship between rain and tenebrionid abundance on non - bird and bird

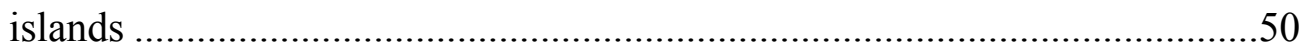

Table 2.4. Average abundance of dominant tenebrionids on non-bird and bird

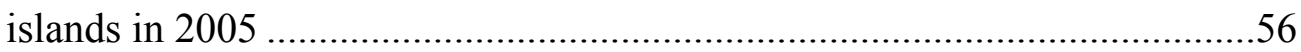




\section{LIST OF FIGURES}

Figure 1.1. Map of the archipelago of Bahía de los Ángeles, Baja California, Mexico .10

Figure 2.2. Average monthly precipitation and temperature in Bahía de los Ángeles

Figure 2.3. Winter precipitation from 1996 - 2016 in Bahía de los Ángeles, Baja

California, Mexico .40

Figure 2.4. Comparison of total plant cover on bird and non-bird islands from $1996-2015$ .45

Figure 2.5. Comparison of tenebrionid abundances on bird and non-bird islands with winter precipitation.

Figure 2.6. Comparison of tenebrionid diversity on bird and non-bird islands

from $1996-2016$ .53

Figure 2.7. Canonical Correspondence Analysis (CCA) of tenebrionid spp. abundance and environmental variables .59 Figure 2.8. Food web of terrestrial communities on the archipelago of Bahía de los Ángeles .62 



\begin{abstract}
Interactions between climate change and the processes that structure coastal communities are poorly understood. Long - term weather patterns that include extreme events (e.g., El Niño Southern Oscillation, or "ENSO") allow us to test hypotheses of how changes in weather (e.g., precipitation) will influence communities over long time frames. One system that is particularly vulnerable to climate changes is the coastal ecotone, which occupies $8 \%$ of the earth's surface. A large exchange of resources (spatial subsidies) link habitats across this ocean - land interface, often with dramatic consequences for the recipient systems. Spatial subsidies such as marine input influence terrestrial communities by providing resources (carrion, nutrients) from the ocean to the land. Marine input is a key component of the dynamics of islands and terrestrial coastal ecosystems, including the archipelago of Bahía de los Ángeles, Mexico. This archipelago of 14 islands is an example of an extremely low - productivity terrestrial habitat, receiving on average only $65 \mathrm{~mm}$ of rainfall a year. Yet these islands are surrounded by a highly productive marine system, where spatial subsidies from the ocean can be as much as 22 times higher than in - situ terrestrial production. Pitfall traps and vegetation transects were used to create an extensive dataset of flora and fauna spanning 20 years on all 14 islands. Analysis of those data has shown that terrestrial communities on this archipelago are responding at a variety of temporal scales to rainfall events, due to the interaction between precipitation and spatial subsidies. A 60 - year record of winter precipitation for this location suggests an important but complicated relationship with ENSO events; years that did encompass El Niño
\end{abstract}


events typically resulted in heavy rainfall relative to non - El Niño years, although this pattern is less consistent than in other regions of North America. This research will continue to enhance international scientific partnership through a broad network of public and private collaboration in Baja California, with data going directly to land managers of this protected archipelago, and has the potential to provide new insights into the generalizability of my findings from this study. 


\section{CHAPTER 1}

\subsection{INTRODUCTION}

\subsubsection{Community Responses to Spatial Subsidies}

A major question of recent ecological research has been to understand the effects of movements of materials, organisms, and energy between local food webs (Allen and Wesner 2016). Large fluxes of resources, or spatial subsidies, link ecosystems directly by affecting the population dynamics of the recipient food webs or indirectly, by then affecting the prey or predators of the subsidized populations (Polis et al. 1997a, Polis et al. 2004a). Non - living material (e.g., detritus) or living material (e.g., prey) from a donor food web can increase productivity of the receiving food web (Allen and Wesner 2016).

Previous research in the archipelago of Bahía de los Ángeles has shown that precipitation interacts with spatial subsides, or allochthonous inputs (Polis et al. 1997), which generally increases primary production, in turn increasing secondary production (e.g., arachnids); however, effects on the dominant taxa (i.e., tenebrionid beetles) are still unclear due to their complicated life history (e.g., changing length of larval stages; Scharf et al. 2015). Tenebrionid diets consist mainly of plant detritus and carrion, making them generalist detritivores and scavengers. Determining the timing of life cycles of tenebrionids is difficult, since larvae live underground, require one or more years to complete development (Knor 1975, de los Santos et al. 1988), and may vary the length of their larval stage depending upon environmental conditions (Scharf et al. 2015). 
Theory (Polis et al. 2004a) suggests that the resulting lags caused by this life history type (long - lived) and trophic strategy (detritivores) may dampen community responses to environmental changes. What is not known are the long term effects of environmental variables such as the timing and magnitude of precipitation and its interaction with spatial subsides on the terrestrial communities of Bahía de los Ángeles. Long - term datasets are uncommon in the field of ecology, providing rare opportunities to understand resource - consumer relationships in realistically complex natural settings. This project expands part of a historical dataset that has focused on the long - term impacts of environmental variables on these communities, making this study important for the consideration of the management and conservation of biodiversity over long time frames.

Coastal habitats vary in primary productivity, and can range from 3 to 3,500 g m-2yr-1 dry mass (Whittaker and Marks 1975, Polis and Hurd 1996). However, waters along the shallow littoral fringe are generally high in productivity and can reach 3,000 - 4,000 g m-2yr-1 in extensive coastlines adjoined by estuaries, reefs, and kelp forests (Polis et al. 2004b).

This contrast in primary productivity across the land - sea interface in Bahía de los Ángeles, coupled with a long history of research at this location on allochthonous inputs (Polis et al. 1997), makes this an ideal natural laboratory in which to research the effects of long - term weather patterns of marine subsidies on detritally - driven systems. This study focused on marine subsidies, which enter terrestrial ecosystems through shore drift and through the influence of seabirds. This study examines the interaction between precipitation and spatial subsidies and 
its effects on community structure to help inform predictions of how future changes in climate may influence similarly arid regions.

\subsubsection{Spatial Subsidies: Shore Drift}

One important pathway by which marine productivity enters the terrestrial food web is through shore drift. Algal wrack, carrion, and dissolved and particulate organics from the pelagic and neritic ocean zones can be deposited onto shores through waves and tides (Orr et al. 2005). In the archipelago of Bahía de los Ángeles, shore drift penetrates the islands in two ways: through algae and carrion (Polis and Hurd 1995). This organic matter is transported via hydrodynamic forces from subtidal, intertidal, and pelagic on to terrestrial ecosystems (Polis et al. 1997a, Hagen et al. 2012) providing a potentially important spatial subsidy to the island communities of Bahía de los Ángeles (Polis and Hurd 1995, Rose and Polis 1998).

The amount and distance of shore drift penetrating an island is based in part on the linear extent, width and slope of the shoreline. In contrast, in - situ terrestrial primary productivity is related to island area (Polis and Hurd 1996). As island size increases, perimeter increases linearly, while area increases as a squared function. Thus the perimeter - to - area ratio decreases with increasing island size and decreasing complexity of island shape. Generally, smaller islands with a high perimeter-to-area ratio will tend to be influenced more by marine input than islands of larger size and similar shape (Anderson et al. 2008). Shore drift provides abundant allochthonous biomass to islands, typically exceeding terrestrial productivity on a per - square - meter basis in the littoral and supralittoral, resulting 
in greater abundances of detritivores and scavengers (Polis and Hurd 1996) which may help to fuel, productive food webs on these islands.

\subsubsection{Spatial Subsidies: Ornithogenic Influence}

Seabird influence on terrestrial ecosystems is considered a form of marine input since seabirds mainly feed in the marine system; later transporting nutrients derived from the marine system in the form of guano or carrion to islands where they roost or nest (Barrett et al. 2005).

Seabirds such as gulls, cormorants, boobies, terns, and pelicans commonly nest or roost on a subset of islands in Bahía de los Ángeles (Anderson and Polis 1999). Seabirds may preferentially congregate on certain islands, potentially to avoid predators and disturbances or be in proximity to an area that would facilitate feeding (Hutchinson 1950, Anderson 1983). Seabirds are important direct contributors of resources to island communities, by providing prey items, carcasses, feathers, eggshells and chicks that do not survive the nesting season (Burger et al. 1978, Polis and Hurd 1996).

In addition to the resources directly contributed by seabirds, colonies indirectly affect island communities by depositing nutrient-rich guano. Ornithogenic guano is high in nitrogen $(\mathrm{N})$ and phosphorus $(\mathrm{P})$ due to seabird diets consisting primarily of fish and squid (Hutchinson 1950). During years of heavy precipitation ("wet years"), ornithogenic guano (i.e., nutrients) spreads, fertilizing the soil and thus facilitating primary productivity (Anderson and Polis 1999). These responses can influence ecosystems for years after a high precipitation event has 
passed, by a slow release of plant and detrital biomass reserves (Polis et al. 1997b). This long lasting response can influence detritivores on this archipelago resulting in lagged responses in population dynamics (Polis et al. 2004a).

In Bahía de los Ángeles, plant communities on nesting and roosting bird islands show dramatic increases in biomass and cover of annuals during rainy years in comparison to non - bird islands (Anderson and Polis 1999). During wet years, bird islands had $1.1-1.7$ times more plant cover (annuals and perennials) and 9.6 - 12.0 times more plant biomass (annuals) than non - bird islands (Polis et al. 1997b). Conversely, in dry years, plant cover decreases more on bird islands than on non - bird islands likely due to water evaporation from the soil, large amounts of dried guano creating toxic soil conditions, seabird trampling, and seabird use of plant material for nest construction (Sánchez - Piñero and Polis 2000).

This increase in plant abundance due to ornithogenic nutrients affects consumer growth and reproduction. Abundances of detritivores, herbivores, and predators on the islands of Bahía de los Ángeles are 3-24 times higher on bird islands than non - bird islands (Anderson and Polis 1999). For example, arthropod growth and egg production are generally limited more by $\mathrm{N}$ than $\mathrm{C}$, thus indicating that consumption of high $\mathrm{N}$ plants or detritus (due to ornithogenic guano) can lead to larger body size and increased fecundity (Mattson 1980, White 1993). While this may be true for some arthropods, long - lived species may not show as fast of a response in growth and egg production, making more research on the dominant community of tenebrionids in this archipelago imperative to understanding different responses of different species. 
Typically bird islands have higher plant species richness than non - bird islands, since bird disturbance (e.g., trampling of plant communities), creates an area more prone to colonization by additional plant species brought in as seeds by seabirds (Ellis 2005). During their nesting activities, seabirds trample and uproot plants altering plant diversity and decreasing plant abundance (Ellis et al. 2006). However, in the archipelago of Bahía de los Ángeles, guano and trampling may lower diversity depending on the amount of guano and density of seabirds (Sánchez - Piñero and Polis 2000). Despite these disturbances, seabirds provide energy and nutrients that support an array of consumer populations. Since these allochthonous resources cannot be renewed without the presence of seabirds, the consumer dynamics and their food webs are mostly donor-controlled (Sánchez - Piñero and Polis 2000), thus island communities depend heavily on ornithogenic subsidies for stability (Polis et al. 1997b). Few research studies have used long - term data to look at the responses of island community structure in Bahía de los Ángeles and more research is needed to understand how responses to rain influences communities over a long time frame on complicated systems such as detrital based ones. 


\subsubsection{Study System}

The archipelago of Bahía de los Ángeles (Figure 1.1) is positioned on the eastern shore in the Midriff region ( $\left.28^{\circ} 55^{\prime} \mathrm{N},-113^{\circ} 30^{\prime} \mathrm{W}\right)$ of the Gulf of California, Baja California, Mexico. This archipelago is part of an international biosphere reserve and is composed of 14 islands including (from north to south) Coronadito, Smith (Coronado), Mitlán, Piojo, Pata, Jorobado, Bota, Flecha, Ventana, Cerraja, Llave, Cabeza de Caballo, Gemelos East, and Gemelos West. These islands are mostly rocky and sparsely covered with vegetation, and range in maximum elevation from $8 \mathrm{~m}$ to $465 \mathrm{~m}$, and in size from $0.02 \mathrm{~km}^{2}$ to $8.7 \mathrm{~km}^{2}$ (Polis et al. 1997b, Pinero and Aalbu 2002). The islands are extremely dry with a mean annual precipitation of $64.7 \mathrm{~mm}$ and mean annual temperature of $34.2^{\circ} \mathrm{C}$ (temperature from 1954 - 2012) (Comisión Nacional del Agua, Mexicali, Mexico).

As in most general desert environments, precipitation is highly variable and unpredictable, generally with $10-50$ rainy days occurring in $3-15$ rain events (Noy-Meir 1973). These bursts of rain may result in pulsed marine input events, which not only contribute to the consistent low levels of terrestrial productivity, but may also trigger pulsed responses of the terrestrial ecosystem. More research is needed on these long - term effects of pulsed inputs on the community composition of Bahía de los Ángeles, as these effects are not well understood as they relate to long - lived, detritivorous taxa. 
Figure 1.1 Map of the archipelago of Bahía de los Ángeles, Baja California, Mexico. Bird islands are indicated in blue and non - bird islands are indicated in green. The red star indicates the weather station that has collected precipitation data for this archipelago. 


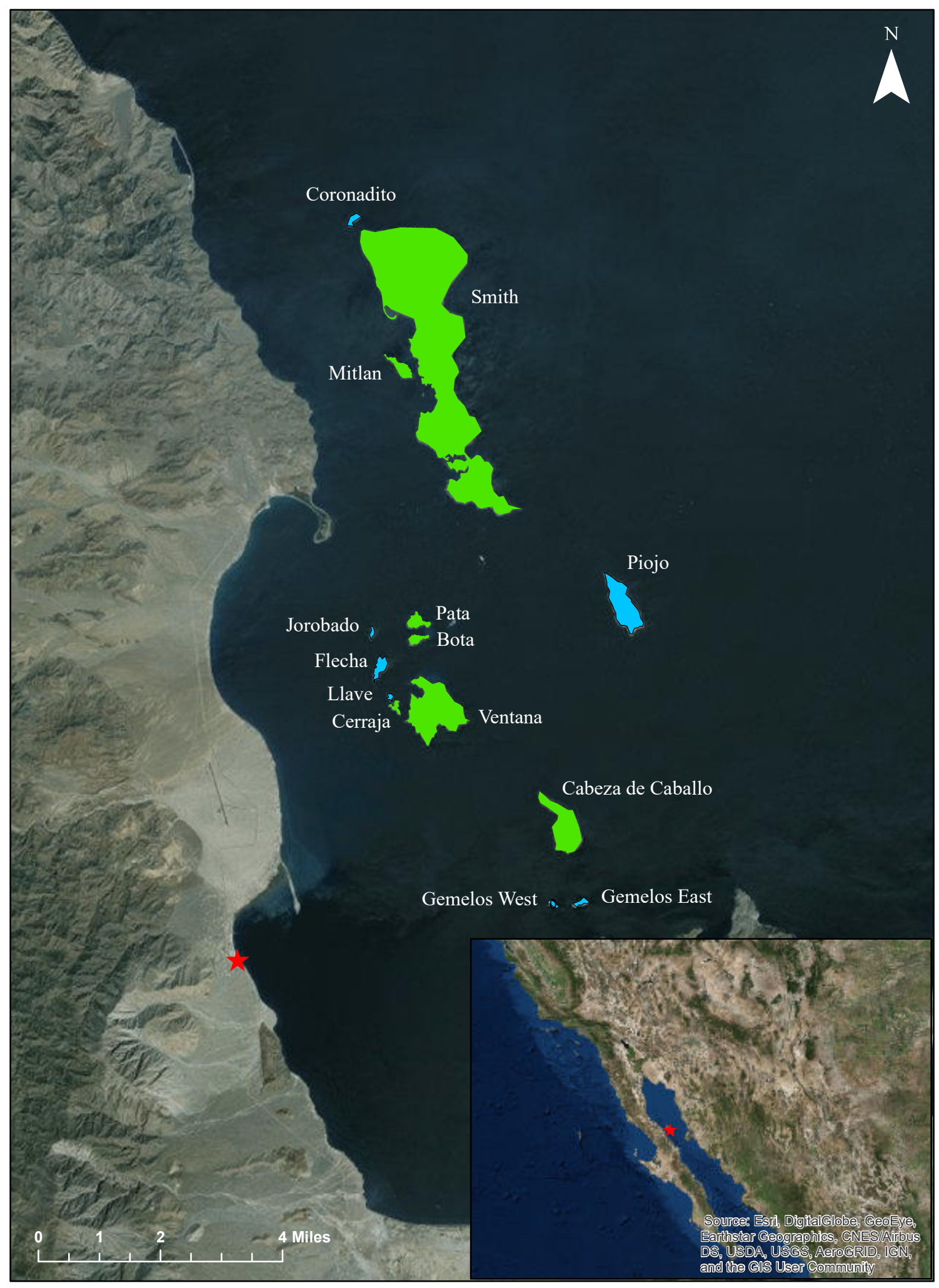




\subsubsection{Effects of El Niño}

El Niño events generally occur every three to six years (Allan et al. 1996). Recent high - resolution climate models suggest that in coming decades El Niñolike conditions will increase in frequency (Timmermann et al. 1999). In certain areas of the world, El Niño events can bring a dramatic increase in rain whereas in other areas, severe droughts may result (Holmgren et al. 2001). Plant cover ranges from $0-4 \%$ on the islands of the Gulf of California during a typical dry year, but plant response increases to $54-89 \%$ of the surface area available for growth during an anomalous wet El Niño year (Schwinning et al. 2004).

El Niño dramatically affects in - situ terrestrial productivity particularly in arid locations since many plants will respond rapidly to a pulsed input of precipitation (Polis et al. 1997b). In Bahía de los Ángeles, most years are dry, while some years receive heavy rainfall during the winter seasons. In 1992, winter precipitation reached 5.4 times the average, and coincided with the $1992-1993 \mathrm{El}$ Niño along the west coast of the Americas. Before that, this archipelago received less than $25 \mathrm{~mm}$ of rainfall in a period of extended drought that lasted from $1986-$ 1991 (Polis et al. 1997b). This pattern of extended droughts coupled with intermittent torrential rainstorms is typical for most of the Baja California peninsula (Shreve and Wiggins 1951). In some cases, the torrential rainfall may result in runoff on this archipelago and is not available for the island ecosystems (Noy-Meir 1973). 


\subsubsection{Vegetation}

The life history strategies of plant communities in deserts include long-lived perennials ( $>50$ years), short-lived perennials ( $<$ ten years), and fast growing annuals ( $<$ four months) (Polis et al. 1997b). Vegetation on the islands of Bahía de los Ángeles is sparse and predominantly consist of low - lying perennials, dominated by cactus (Opuntia spp.), Agave spp., and Atriplex spp. shrubs (Sánchez - Piñero and Polis 2002). Perennials are more abundant on non - bird islands, and in particular "wet years", annuals (e.g., Amaranthus spp, Cryptantha spp.) will generally be more abundant on bird islands, most likely due to enhanced nutrient availability from ornithogenic guano (Polis et al. 1997b).

Since the archipelago of Bahía de los Ángeles is low in terrestrial productivity and typically dominated by perennial plants, there will be lagged responses to rainfall. Additionally, there are lags between annual growth and break down, and thus lags associated with life span of tenebrionid larvae, so although detritivores are feeding on the decay of annual plants, the effects of rainfall may not be immediately obvious, if at all.

\subsubsection{Fauna}

Insular fauna may be different on each island in an archipelago. Individual islands serve as spatially discrete entities and may support different combinations of predators (Fukami et al. 2006). Animal communities on the islands of Bahía de los Ángeles include species of seabirds, snakes, lizards, rodents, web - building spiders and ground - dwelling arthropods (Case et al. 2002). The arthropods, which 
dominate island communities, include algivores, herbivores, scavengers, detritivores, seabird ectoparasites, and predators (Polis and Hurd 1996). Making up approximately $65 \%$ of all organisms, arthropod species (Groombridge 1992) are good correlates for species diversity (Duelli and Obrist 1998) and significantly influence ecosystem processes (Schweiger et al. 2005).

Tenebrionid beetles are one of the most common terrestrial arthropods in Bahía de los Ángeles, constituting 70\% of the total number of arthropods in this archipelago (excluding ants) (Sánchez - Piñero and Aalbu 2002). The Tenebrionidae are part of a highly evolved and diverse family, with about 1000 genera that are exclusively adapted to arid environments (Crawford 1991). Tenebrionid beetles include both short and long - living species, adults usually living several years (Allsop 1980, Crawford 1981). Determining the life cycles of tenebrionids is difficult since larvae are mostly belowground dwellers which require one or more years to complete development (De Los Santos et al. 1988). On the islands of Bahía de los Ángeles, 20 species of tenebrionids can be found, with $60.5 \%$ of all individuals belonging to the dominant taxa of Argoporis apicalis (Blaisdell 1943), Triphalopsis californicus (Doyen 1982), and Cryptoglossa spiculifera (Cline and Shockley 2010, Sánchez - Piñero and Polis 2000).

Tenebrionid development is scarcely known (Case et al. 2002), but experiments with tribolium have shown that larvae are able to shortening or lengthening their development depending on environmental conditions, such as food availability (Crawford 1991). Thus, when food is available, they are able to develop as larvae for longer periods of time, becoming larger in size; contrarily, 
larvae are able to develop faster, being smaller in size, when food is scarce. Thus, differences in the lagged responses to rain could be due to differences in life histories of different tenebrionid species living on islands with different resource availability (i.e., bird and non - bird islands).

\subsubsection{Project Goal and Objectives}

Previous studies have revealed that rainfall interacts with marine subsidies in this arid region to increase the productivity and alter the diversity of annual plants, arachnids, and other terrestrial arthropods (Polis and Hurd 1996). This information is needed to help predict the effects of climate change on coastal ecosystems and communities. However, the effects of these environmental processes on taxa with lagged responses, such as detritivores and long - lived species, are not as well understood. These taxa dominate these arid islands in most years (i.e., dry years), and contribute to the base of the food web in this, as well as many other ecosystems. Therefore, the goal of this project was to paint a more complete picture of how long - term weather patterns (e.g., precipitation) interact with linkages between adjacent coastal and marine ecosystems to influence natural community structure, in particular detritivores. This goal was met by testing the hypotheses associated with the following research objectives: 
1) How do the timing and magnitude of precipitation interact with island bird status to affect island community composition?

2) How do the timing and magnitude of precipitation interact with island environmental characteristics to affect island community composition? 


\subsubsection{Statement of Hypotheses}

$\mathrm{H}_{0}$ : The timing and magnitude of precipitation do not interact with island bird status to affect island community composition.

$\mathrm{H}_{0}$ : The timing and magnitude of precipitation do not interact with island environmental characteristics to affect island community composition 


\subsection{References}

Allan, R., J. Lindesay, and D. Parker. 1996. El Niño southern oscillation \& climatic variability. CSIRO publishing.

Allen, D. C., and J. S. Wesner. 2016. Synthesis: comparing effects of resource and consumer fluxes into recipient food webs using meta-analysis. Ecology 97:594-604.

Allsopp, P. 1980. The biology of false wireworms and their adults (soil-inhabiting Tenebrionidae)(Coleoptera): a review. Bulletin of Entomological Research 70:343-379.

Anderson, D. W. 1983. The seabirds. Pages 246-264 in T. J. Case and M. L. Cody, editors. Island Biogeography in the Sea of Cortez. University of California Press, Berkeley, California, USA.

Anderson, W. B., and G. A. Polis. 1999. Nutrient fluxes from water to land: seabirds affect plant nutrient status on Gulf of California islands. Oecologia 118:324-332.

Anderson, W. B., D. A. Wait, and P. Stapp. 2008. Resources from another place and time: Responses to pulses in a spatially subsidized system. Ecology 89:660-670.

Barrett, K., W. B. Anderson, D. A. Wait, and L. L. Grismer. 2005. Marine subsidies alter the diet and abundance of insular and coastal lizard populations. Oikos 109:145-153.

Blaisdell, F. E. 1943. Contributions Toward a Knowledge of the Insect Fauna of Lower California: No. 7. Coleoptera: Tenebrionidae.

Case, T. J., M. L. Cody, and E. Ezcurra. 2002. A new island biogeography of the Sea of Cortés. Oxford University Press on Demand.

Cline, A. R., and F. W. Shockley. 2010. 10.6. Biphyllidae LeConte, 1861. Handbook of Zoology. Arthropoda: Insecta. Coleoptera, Beetles 2:306311.

Crawford, C. S. 1991. The community ecology of macroarthropod detritivores. Ecology of Desert Communities. University of Arizona Press, Tucson.

Crawford, C. S. 1981. The Array of Desert Invertebrates. Pages 19-29 Biology of Desert Invertebrates. Springer. 
De Los Santos, A., C. Montes, and L. R. Diaz. 1988. Life histories of some darkling beetles (Coleoptera: Tenebrionidae) in two mediterranean ecosystems in the lower Guadalquivir (Southwest Spain). Environmental Entomology 17:799-814.

Doyen, J. 1982. New species of Tenebrionidae from western North America (Coleoptera). Pan-Pacific entomologist.

Duelli, P., and M. K. Obrist. 1998. In search of the best correlates for local organismal biodiversity in cultivated areas. Biodiversity and conservation 7:297-309.

Ellis, J. C. 2005. Marine Birds on Land: A Review of Plant Biomass, Species Richness, and Community Composition in Seabird Colonies. Plant Ecology 181:227-241.

Ellis, J. C., J. M. Fariña, and D. W. Jon. 2006. Nutrient Transfer from Sea to Land: The Case of Gulls and Cormorants in the Gulf of Maine. Journal of Animal Ecology 75:565-574.

Fukami, T., D. A. Wardle, P. J. Bellingham, C. P. Mulder, D. R. Towns, G. W. Yeates, K. I. Bonner, M. S. Durrett, M. N. Grant-Hoffman, and W. M. Williamson. 2006. Above-and below-ground impacts of introduced predators in seabird-dominated island ecosystems. Ecology letters 9:1299-1307.

Groombridge, B. 1992. Global biodiversity: status of the earth's living resources. Chapman \& Hall.

Hagen, E. M., K. E. McCluney, K. A. Wyant, C. U. Soykan, A. C. Keller, K. C. Luttermoser, E. J. Holmes, J. C. Moore, and J. L. Sabo. 2012. A metaanalysis of the effects of detritus on primary producers and consumers in marine, freshwater, and terrestrial ecosystems. Oikos 121:1507-1515.

Holmgren, M., M. Scheffer, E. Ezcurra, J. R. Gutiérrez, and G. M. J. Mohren. 2001. El Niño effects on the dynamics of terrestrial ecosystems. Trends in Ecology \& Evolution 16:89-94.

Hutchinson, G. E., -. 1950. Survey of existing knowledge of biogeochemistry. 3, The biogeochemistry of vertebrate excretion. Bulletin of the AMNH ; v. 96. New York : [American Museum of Natural History].

Mattson, W. J. 1980. Herbivory in relation to plant nitrogen-content. Annual Review of Ecology and Systematics 11:119-161. 
Noy-Meir, I. 1973. Desert Ecosystems: Environment and Producers. Annual Review of Ecology and Systematics 4:25-51.

Orr, M., M. Zimmer, D. E. Jelinski, and M. Mews. 2005. Wrack deposition on different beach types: Spatial and temporal variation in the pattern of subsidy. Ecology 86:1496-1507.

Pinero, F. S., and R. L. Aalbu. 2002. Tenebnonid beetles. A new island biogeography of the sea of cortés: 129 .

Polis, G. A., W. B. Anderson, and R. D. Holt. 1997a. Toward an integration of landscape and food web ecology: The dynamics of spatially subsidized food webs. Annual Review of Ecology and Systematics 28:289-316.

Polis, G. A., and S. D. Hurd. 1995. Extraordinarily high spider densities on islands: flow of energy from the marine to terrestrial food webs and the absence of predation. Proceedings of the National Academy of Sciences 92:4382-4386.

Polis, G. A., and S. D. Hurd. 1996. Linking Marine and Terrestrial Food Webs: Allochthonous Input from the Ocean Supports High Secondary Productivity on Small Islands and Coastal Land Communities. The American Naturalist 147:396-423.

Polis, G. A., S. D. Hurd, C. T. Jackson, and F. S. Pinero. 1997b. El Niño effects on the dynamics and control of an island ecosystem in the Gulf of California. Ecology 78:1884-1897.

Polis, G. A., M. E. Power, and G. R. Huxel. 2004a. Food webs at the landscape level. University of Chicago Press.

Polis, G. A., F. Sánchez-Piñero, P. T. Stapp, W. B. Anderson, and M. D. Rose. 2004b. Trophic flows from water to land: marine input affects food webs of islands and coastal ecosystems worldwide. Food webs at the landscape level. University of Chicago Press, Chicago, Illinois, USA:200-216.

Rose, M. D., and G. A. Polis. 1998. The Distribution and Abundance of Coyotes: The Effects of Allochthonous Food Subsidies from the Sea. Ecology 79:998-1007.

Sánchez - Piñero, F., and G. A. Polis. 2000. Bottom-up dynamics of allochthonous input: Direct and indirect effects of seabirds on islands. Ecology 81:3117-3132.

Sánchez - Piñero, F., and R. L. Aalbu. 2002. Tenebnonid Beetles. A new island biogeography of the Sea of Cortés:129. 
Scharf, I., H. Braf, N. Ifrach, S. Rosenstein, and A. Subach. 2015. The effects of temperature and diet during development, adulthood, and mating on reproduction in the red flour beetle. PloS one 10:e136924.

Schweiger, O., J.-P. Maelfait, W. v. Wingerden, F. Hendrickx, R. Billeter, M. Speelmans, I. Augenstein, B. Aukema, S. Aviron, and D. Bailey. 2005. Quantifying the impact of environmental factors on arthropod communities in agricultural landscapes across organizational levels and spatial scales. Journal of applied Ecology 42:1129-1139.

Schwinning, S., O. E. Sala, M. E. Loik, and J. R. Ehleringer. 2004. Thresholds, memory, and seasonality: understanding pulse dynamics in arid/semi-arid ecosystems. Springer.

Shreve, F., and I. L. Wiggins. 1951. Vegetation of the Sonoran desert. Carnegie institution of Washington.

Timmermann, A., J. Oberhuber, A. Bacher, and M. Esch. 1999. Increased El Niño frequency in a climate model forced by future greenhouse warming. Nature 398:694.

White, T. C. R. 1993. The inadequate environment : nitrogen and the abundance of animals. Springer-Verlag, Berlin; New York.

Whittaker, R. H., and P. L. Marks. 1975. Methods of Assessing Terrestrial Productivty. Pages 55-118 Primary productivity of the biosphere. Springer. 


\section{CHAPTER 2}

\section{LONG - TERM CHANGES IN A SPATIALLY SUBSIDIZED INSULAR ECOSYSTEM IN BAHÍA DE LOS ÁNGELES, BAJA CALIFORNIA, MEXICO}

\subsection{Introduction}

The coastal ecotone is an important ecosystem that is formed by the ocean - land interface. Only occupying $8 \%$ of the earth's surface, the coastal ecotone encompasses about two thirds of our human population and an abundant amount of biodiversity (Levin et al. 2001). Large fluxes of resources (spatial subsidies) link habitats across this ecotone, often with dramatic consequences for the recipient systems (Vetter 1995, Rodríguez 2003). Marine - derived spatial subsidies strongly influence the food webs of terrestrial island communities either directly, by affecting the population dynamics of the receiving communities, or indirectly, by affecting the prey or predators of the subsidized populations (Polis et al. 1997a, Polis et al. 2004).

Sporadic heavy rains also greatly affect terrestrial island communities by increasing the population of desert ephemerals (Ostfeld and Keesing 2000). This increase of primary production through precipitation and its beneficial interaction with spatial subsidies, fuels island food webs, and can only be understood in context through examining the long - term effects of spatial subsidies on these typically resource - limited environments. Located in the Gulf of California, the archipelago of Bahía de los Ángeles is considered a low terrestrial productivity environment, with high temperatures and low rainfall (Polis and Hurd 1996). The archipelago receives its main source of resources through allochthonous input, or spatial 
subsidies, which provides $2-20$ times more organic material than in - situ terrestrial productivity (Polis and Hurd 1996). These allochthonous nutrient inputs are driving factors that greatly contribute to system - wide productivity and dynamics (Anderson and Polis 1999).

Marine subsidies enter terrestrial food webs through shore drift of algae and carrion, as well as through seabirds, as they provide organic material and nutrients to these habitats (Anderson and Polis 1999) by providing prey items, carcasses, excreta, and chicks that do not survive the nesting season (Burger et al. 1978, Polis and Hurd 1996).

In addition to the resources directly contributed by seabirds, colonies indirectly affect island communities by depositing nutrient - rich guano (Sánchez - Piñero and Polis 2000). During years of heavy precipitation, ornithogenic guano spreads and fertilizes the soil, facilitating primary productivity (Anderson and Polis 1999). This productivity can influence population dynamics of these insular ecosystems for years after a high - precipitation event has passed, due to the slow release of plant and detrital biomass reserves (Polis et al. 1997b). This process allows for primary producers and consumers to survive during years of little or no precipitation and low terrestrial primary productivity (Polis et al. 1997b).

In this study, we focused on how the dominant arthropod and plant communities on the islands of Bahía de los Ángeles responded to long - term weather patterns (specifically precipitation regime), and island characteristics such as guano cover, plant cover, and soil moisture. Since drought affects many biological factors and is location - specific in its definition, we used soil moisture 
to provide a collective measure of water availability and drought (Sheffield and Wood 2008).

This project expands part of a historical data - set that has focused on the long - term impacts of environmental factors on terrestrial communities of Bahía de los Ángeles. Long - term data are rare in ecology, but since many processes occur over long timescales, this research is valuable for developing a fuller understanding of how ecosystems in the archipelago of Bahía de los Ángeles function. Assessing the effects of climatic perturbations will allow for the management and conservation of biodiversity over long time frames.

In this study, we assessed the community composition of tenebrionid beetle communities within the archipelago of Bahía de los Ángeles over a 20 - year time period. Tenebrionids are detritivores that have a complicated life history since larvae require one or more years to complete development (Knor 1975, de los Santos et al. 1988) and may vary considerably depending upon environmental conditions (Scharf et al. 2015). Theory (Polis et al. 2004a) demonstrates that the resulting lags caused by this life history type (long - lived) and trophic strategy (detritivores) may dampen community responses to environmental changes. This study examines the interaction between precipitation and spatial subsidies and its effects on community structure to help inform predictions of how future changes in climate may influence similarly arid regions.

The goals of this study were to test the relative importance of in - situ processes (e.g., terrestrial productivity) in insular ecosystems, with outside factors of spatial subsidy and precipitation in influencing community dynamics through 
space and time. This research illuminated the underlying mechanisms of spatial subsidy by examining how subsidies change through time, and the relationship between those processes and island community structure, by analyzing how the timing and magnitude of precipitation interacted with island environmental characteristics and seabird use to affect island assemblages. Understanding the mechanisms and extent of ecosystem connectivity is critical for predicting future change of coastal systems, as well as for land management and conservation.

\subsection{Methods}

\subsubsection{Study Site}

The archipelago of Bahía de los Ángeles is on the eastern shore in the Gulf of California, Baja California, Mexico. This archipelago is part of an international biosphere reserve and comprises 14 islands including (from north to south) Coronadito, Smith (Coronado), Mitlán, Piojo, Pata, Jorobado, Bota, Flecha, Ventana, Cerraja, Llave, Cabeza de Caballo, Gemelos East, and Gemelos West (Figure 1.1). The islands of Bahía de los Ángeles are one of the driest places in North America, with a mean annual precipitation of $65.1 \mathrm{~mm}$ (precipitation from 1954 - 2016) and mean annual temperature of $34.2^{\circ} \mathrm{C}$ (temperature from $1954-$ 2012) (Comisión Nacional del Agua, Mexicali, Mexico).

Although this archipelago is a low - productivity terrestrial environment, it is immersed in a highly productive sea, characterized by strong tidal mixing and upwelling (Anderson et al. 2008). This contrast in primary productivity, coupled 
with a long history of research at this location on allochthonous inputs (Polis et al. 1997) make this an ideal natural laboratory in which to research the impacts of climate and marine subsidies on terrestrial communities. 
Figure 2.2 Average monthly precipitation and temperature in Bahía de los Ángeles. Precipitation data was obtained from 1996 - 2016. Monthly temperature was not collected between 2013 - 2016 and (error bars were removed for clarity). 


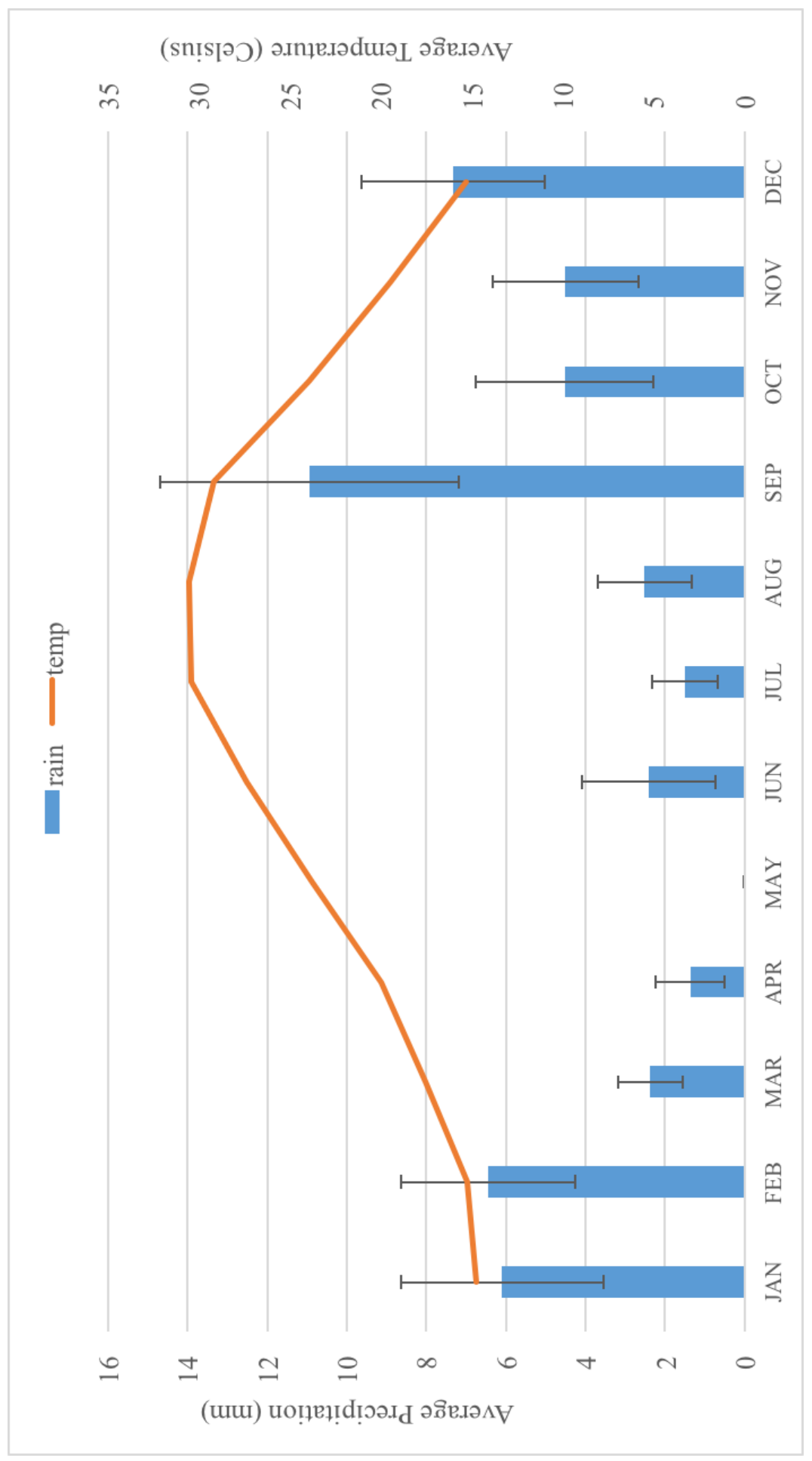




\subsubsection{Field Techniques}

\subsubsection{Sampling of Tenebrionidae}

This research was conducted using carrion - baited pitfall traps to sample the key taxon of tenebrionid beetle abundance and diversity from 1996 - 2016 on the archipelago of Bahía de los Ángeles. Baited traps were used because carrion attracts Tenebrionidae and enhances the capture rate; these traps also provide an unbiased method of estimating relative abundances of tenebrionid beetles (Polis 1997, Sánchez - Piñero and Polis 2000).

Pitfall traps were constructed by placing a $20 \mathrm{~cm}$ diameter funnel in a plastic cup ( $9 \mathrm{~cm}$ in diameter) flush with the ground. The funnel was covered by a $2 \times 2$ cm wire mesh and baited with 200g of fish (Paralabrax spp.) (Sánchez - Piñero and Polis 2000). Large rocks were placed on top of the trap to prevent larger animals from disturbing the trap and/or taking the bait. Traps remained on each island for six days, in order to prevent complete desiccation of carrion and the deterioration of captured specimens. The traps were then recovered, and the tenebrionid beetles were identified to species level, counted, recorded, and released.

Sampling of tenebrionidae was conducted during the summer (June and July) each year, to avoid disturbing birds during the nesting season. Depending on the size of the island, five (small island) to 16 traps (large island) were placed $>100$ $\mathrm{m}$ inland, to prevent possible shore - drift effects on terrestrial arthropod populations (Sánchez - Piñero and Polis 2000).

There are data gaps for certain years/islands due to weather and logistical difficulties, with missing samples from Gemelos East and Gemelos West in 2006 
and 2011, Miltan in 2008, and Gemelos in 2014. In 2002, no sampling could be conducted from any of the islands.

\subsubsection{Plant Cover}

Plant cover was used as a proxy for terrestrial primary productivity and was estimated using the point- quarter method (Cottam and Curtis 1956). This method was performed along two perpendicular $100-250 \mathrm{~m}$ transects on each island. The percentage of ground covered by plants was assessed at every 5- 10 randomly assigned steps. Plant cover was estimated in the four $1-\mathrm{m}^{2}$ plots surrounding the point defined by that step. Transects were placed to exclude cliffs and to allow for the sampling of microhabitats such as alluvial plains and talus slopes in their approximate proportions of total island area. Two observers independently assessed cover and resolved any conflicts prior to recording the data (Polis et al. 1997b). In 2002, 2003, 2008 - 2010, 2012 - 2014, and 2016, plant cover was not assessed.

\subsubsection{Ornithogenic Guano}

Since a continuum of seabird influence exists among the islands of Bahía de los Ángeles, islands were characterized as non - bird islands and bird islands (Table 2.1) based on the amount of guano cover. Guano cover was estimated using the point quarter method and was used as an index of seabird nutrient input. The average amount of guano covered $34.5 \%$ of bird islands (range: $13.6-76.6 \%$ ) whereas guano cover averaged $<6 \%$ on non - bird islands (Anderson and Polis 1999, Sánchez - Piñero and Polis 2000). There is limited evidence to explain 
seabird preference in island characteristics. It is thought that birds select certain islands to nest due to factors such as the proximity to rich feeding sites, the absence of predation and human disturbance (Everett and Anderson 1991,Velarde and Anderson 1994). 
Table 2.1. Island physical characteristics of Bahía de los Ángeles; location, size, perimeter- to- area (P/A) ratio, seabird status and guano cover (Polis et al. 1997b, Anderson and Polis 1999). 


\begin{tabular}{|c|c|c|c|c|c|}
\hline ISLAND & ${ }^{\circ} \mathrm{N} /{ }^{\circ} \mathrm{W}$ & $\begin{array}{l}\text { AREA } \\
(\mathrm{KM} 2)\end{array}$ & $\begin{array}{l}\mathrm{P} / \mathrm{A} \\
\mathrm{RATIO}\end{array}$ & StATUS & $\begin{array}{l}\text { GUANO } \\
\text { COVER } \\
(\%)\end{array}$ \\
\hline BOTA & $\begin{array}{l}29,01^{\prime} / 113 \\
31\end{array}$ & 0.093 & 15.4 & NON- BIRD & 0 \\
\hline $\begin{array}{l}\text { CABEZA } \\
\text { CABALLO }\end{array}$ & $\begin{array}{l}28,58 \% / 113 \\
29\end{array}$ & 0.704 & 5.6 & NON- BIRD & 0 \\
\hline CERRAJA & $\begin{array}{l}29,00 \% / 113 \\
31,\end{array}$ & 0.037 & 25.9 & NON- BIRD & 5.5 \\
\hline CORONADITO & $\begin{array}{l}29,10^{\prime} / 113 \\
36^{\prime}\end{array}$ & 0.072 & 15.2 & BIRD & 13.6 \\
\hline FLECHA & $\begin{array}{l}29,00^{\prime} / 113 \\
31\end{array}$ & 0.129 & 13.0 & BIRD & 23.9 \\
\hline GEMELOS EAST & $\begin{array}{l}28 \\
29\end{array}, 57^{\prime} / 113$ & 0.047 & 18.9 & BIRD & 20.6 \\
\hline GEMELOS WeSt & $\begin{array}{l}28 \\
28\end{array}, 57^{\prime} / 113$ & 0.020 & 31.0 & BIRD & 76.6 \\
\hline JOROBADO & $\begin{array}{l}29,01 \% / 113 \\
31,\end{array}$ & 0.039 & 22.9 & BIRD & 21.5 \\
\hline LLAVE & $\begin{array}{l}29,00 \% / 113 \\
31\end{array}$ & 0.022 & 26.3 & BIRD & 23.5 \\
\hline MITLAN & $\begin{array}{l}29,06^{\prime} / 113 \\
31\end{array}$ & 0.156 & 12.0 & NON- BIRD & 0 \\
\hline PATA & $\begin{array}{l}29,01^{\prime} / 113 \\
31,\end{array}$ & 0.136 & 11.6 & NON- BIRD & 0 \\
\hline PIOJO & $\begin{array}{l}29,01^{\prime} / 113 \\
31\end{array}$ & 0.533 & 6.1 & BIRD & 8.5 \\
\hline SMITH & $\begin{array}{l}29,04^{\prime} / 113 \\
31\end{array}$ & 8.684 & 2.3 & NON- BIRD & 0 \\
\hline VENTANA & $\begin{array}{l}29,00 \% / 113 \\
31\end{array}$ & 1.275 & 4.0 & NON- BIRD & 0 \\
\hline
\end{tabular}




\subsubsection{Meteorological Data}

The weather station located in Bahía de los Ángeles is approximately 15.5 $\mathrm{km}$ from the most distant bay island, and all islands in the archipelago lie within 20 $\mathrm{km}$ of each other (Figure 1.1). The weather station has recorded rainfall, temperature, humidity and barometric pressure daily since 1954 and has been provided to us by Isaac Orozco, Dr. Sergio Reyes Coca, Ruben Roa Quifionez, and Santiago Higareda of CICESE and Universidad Autonoma de Baja California, and also from the Comision Nacional del Agua.

\subsection{Precipitation}

Precipitation was calculated for the last 12 months of precipitation prior to sampling in July. Following the criterion of Polis et al. (1997b), precipitation was also measured from December - March prior to sampling based on the importance of ground - penetrating winter rain for vegetation dynamics (Dice 1939, Crosswhite and Crosswhite 1982).

Daily rainfall data were available from 2002 - 2016 and large rain events were excluded from analyses (three standard deviations from the mean of daily rain events) as to remove any large rain events that may not benefit plants or animals due to runoff. Additionally, precipitation values below $30 \mathrm{~mm}$ were removed from analyses since at such low levels, there are no relationships between precipitation and primary production in desert environments such as Bahía de los Ángeles (Turner and Randall 1989). This study included two strong El Niño events (1998 
and 2016) with moderate El Niño events occurring in 2003, 2005, 2007, and 2010 based on the Multivariate ENSO Index (Wolter and Timlin 1998).

\subsection{Soil Moisture}

To provide a collective measure of water availability and drought (Sheffield and Wood 2008) for our study system, soil moisture estimates for Bahía de los Ángeles were produced with the Giovanni online data system, developed and maintained by the NASA GES DISC (https://disc.sci.gsfc.nasa.gov/uui/datasets/NLDAS_NOAH0125_H_002/summary \#documentation, 12/6/16). Soil moisture was simulated in $\mathrm{kg} / \mathrm{m} 2$ for the top 10 cm of soil (Xia et al. 2015a, b).

The data are in $1 / 8^{\text {th }}$ degree grid spacing, dating from January of 1979 to the present. Data included land surface parameters that are simulated from the Noah land- surface model (LSM) for Phase 2 of the North American Land Data Assimilation System (NLDAS- 2). The temporal resolution is hourly while the results were summarized to monthly values in this study (Xia et al. 2012).

\subsubsection{Data Analysis}

To assess abundances of tenebrionids on each island, the average number of beetles per pitfall trap were calculated on each island for each year. All abundance averages were then square root transformed to meet the assumptions of normality. Islands were categorized by seabird status (i.e., bird and non - bird) as 
determined by percent guano cover $(<6 \%$ guano results in non - bird classification $)$ (Polis et al. 1997, Sánchez - Piñero and Polis 2000). A $t$ test for paired comparisons (Sokal and Rolf 1995) were used to compare tenebrionid abundances between island types (bird status) for the 20 years included in this study.

Multivariate general linear model (GLM) regressions (restricted sigma parameterization) were also performed to determine relationships between average tenebrionid abundances grouped by island status (i.e., bird and non - bird) as the dependent variable and precipitation as the explanatory variable (using above methods of calculating precipitation). Regressions were carried out considering rainfall in the same year of sampling, and also with a one - year and two - year lagged response of tenebrionids, since tenebrionids usually require one - two years to complete larval development (Knor 1975, De Los Santos et al. 1988).

Multivariate general linear model (GLM) regressions (restricted sigma parameterization) were also performed to determine relationships between average plant cover (arcsin square root transformed) as the dependent variable and precipitation as the explanatory variables across island types and through time. Significance of regression results were adjusted using a Bonferroni (Carlo 1936) corrected $\alpha$ of 0.0125 in order to correct for random correlation significance due to multiple comparisons.

In addition to analysis of tenebrionid and plant cover means, linear regressions of tenebrionid and plant variances were completed in order to determine whether precipitation affected the variability of plant cover and tenebrionid 
abundances among islands. In order to determine whether patterns of variances (using SD) differed between island types (bird status), two - tailed $t$ tests (Zimmerman and Zumbo 1993) were used on both tenebrionid variances and plant variances on bird and non - bird islands.

Species diversity indices for tenebrionid abundance averages on each island were calculated using Simpson's Index $\left(D_{s}\right)$ (Simpson 1949). $D_{s}$ diversity values were then averaged for each island status (i.e., bird and non - bird). This index was used since it focuses on dominant species and therefore limiting the effect of rare species on diversity (Magurran 2013). Averages and standard errors were calculated for each individual island. $\mathrm{D}_{\mathrm{s}}$ diversity was compared across island types using one - way ANOVA analyses (Christensen 1987).

Non - metric multidimensional scaling (NMDS) was used in PRIMERv6 software (Clarke and Gorley 2006) to visualize changes in tenebrionid community structure through time and space on varying island types. Tenebrionid average abundances were grouped by island status for each year from 1996 - 2016 . Sampling was not conducted in 2002.

In order to determine statistical differences in communities between bird and non - bird islands, Analysis of Similarity (ANOSIM) was used in PRIMERv6 software (Clarke and Gorley 2006). Similarity Percentage Analyses (SIMPER) (Anderson et al. 2008) were then run on each island for each year to determine which communities contributed to these dissimilarities. 
Canonical Correspondence Analysis (CCA) was performed in CANOCO 5 software (Šmilauer and Lepš 2014). CCA is a direct gradient analysis technique, where species composition is directly related to measured environmental variables (Palmer 1993). CCA was used to explain the percentage of variation in tenebrionid species composition indicated by the environmental variables used (i.e., soil moisture, guano cover, plant cover, and winter rain).

\subsection{Results}

\subsubsection{Precipitation}

Precipitation varies across times, magnitudes, and durations and affects ecosystems in a number of ways. El Niño events are generally associated with heavy precipitation in certain areas of the world (Holton and Dmowska 1989) and in our study region, four of the years with the highest total winter rain during 1996 - 2016 were El Niño years (Figure 2.3). Over the past 60 years there was higher winter precipitation during El Niño events $(48.7 \mathrm{~mm} \pm 10.70)$ relative to non $-\mathrm{El}$ Niño years $(20.1 \mathrm{~mm} \pm 3$; two- tailed $t$ test: d.f. $=17, t=2.57, \mathrm{P}=0.02)$, however some years were exceptions. For example, the 2007 and 2016 El Niño brought 4.6 $\mathrm{mm}$ and $9 \mathrm{~mm}$ of winter rain, respectively, while $30.1 \mathrm{~mm}$ of winter rain fell in 2008, a non - El Niño year (for comparison, average winter rainfall between 1996 -2016 was $21 \mathrm{~mm})$. 


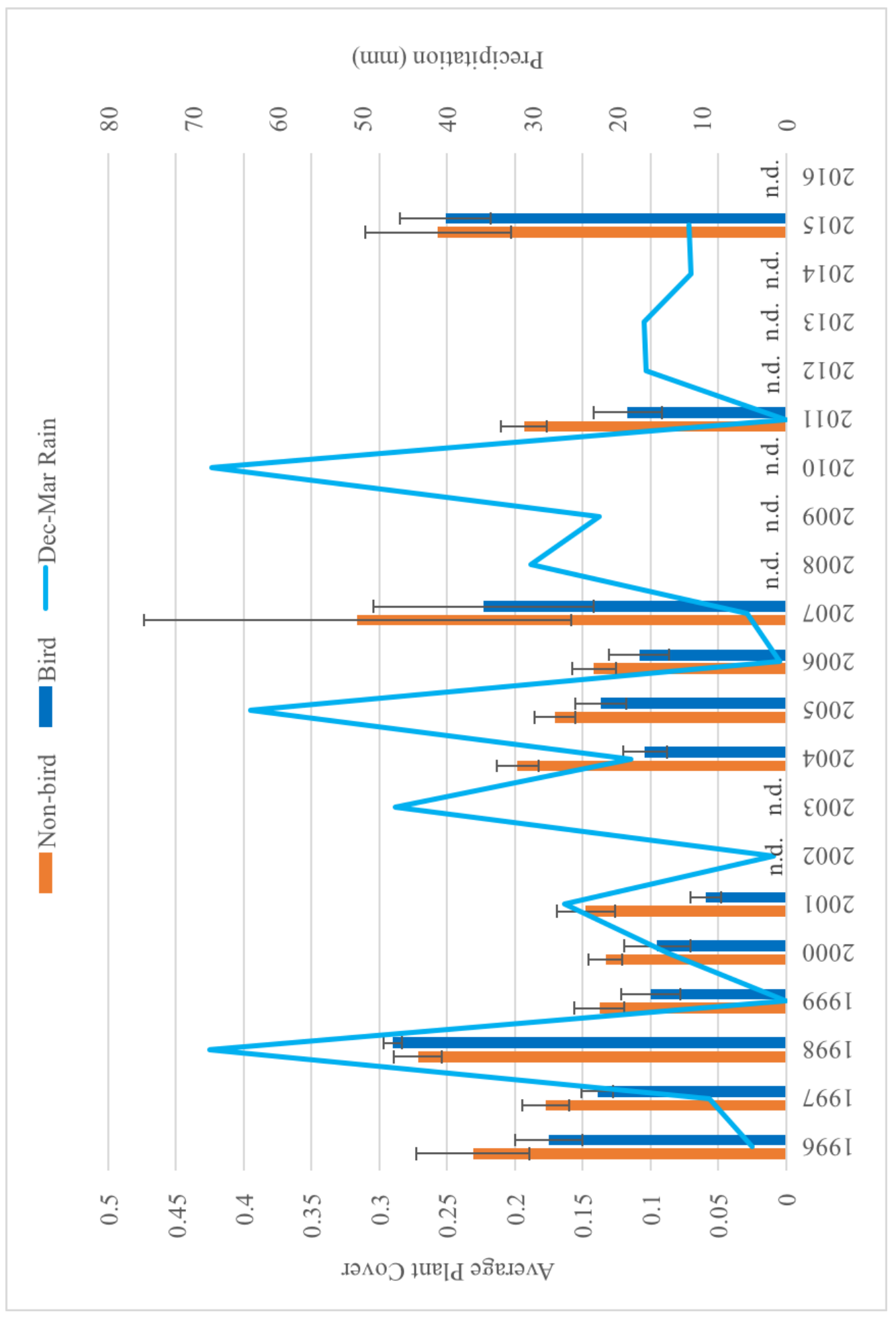


Figure 2.3 Winter (December - March) precipitation from 1996 - 2016 in Bahía de los Ángeles, Baja California, Mexico. El Niño years are shaded in gray $(1998,2003,2005,2007,2010$, and 2016). 


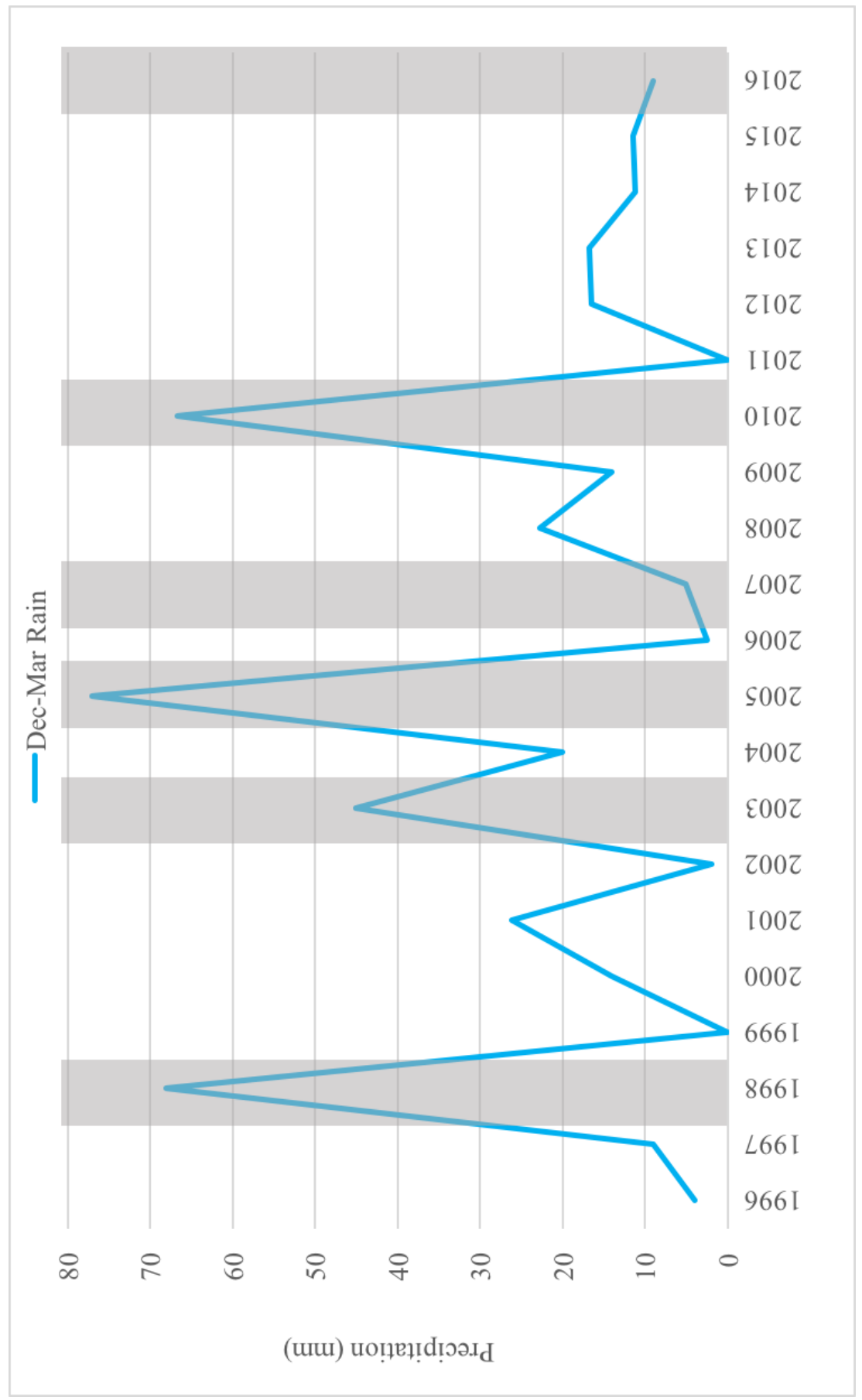




\subsubsection{Vegetation}

Plant cover was similar or higher on non - bird islands than on bird islands for all years that plant cover was assessed (Figure 2.4). Increased plant cover did not always coincide with increased rainfall, and tended to be higher during wet years on non - bird islands except for 1998 (Figure 2.4). Average plant cover was not related to winter precipitation for bird and non - bird islands (Table 2.2).

Using annual rain, there were no significance relationships after Bonferroni corrections were made between plant cover on either bird islands and non - bird islands (Table 2.2). Additionally, plant cover variance was similar between bird islands $(0.05 \pm 0.008)$ and non - bird islands $(0.08 \pm 0.02, t=1.3, \mathrm{P}=0.22$, d.f. $=$ 14; two- tailed $t$ test). 
Table 2.2 Univariate results from a multivariate GLM regression (sigma restricted parameterization) for the relationship between rain (winter and annual) and plant cover (arcsin square root transformed) on non - bird and bird islands. 


\begin{tabular}{|c|c|c|c|c|c|c|}
\hline \multirow[b]{2}{*}{ Effect } & \multicolumn{3}{|l|}{ Non - Bird } & \multicolumn{3}{|l|}{ Bird } \\
\hline & Coefficients & $\begin{array}{l}\mathrm{F} \\
(\mathrm{d} . \mathrm{f} .=1,10)\end{array}$ & $\mathrm{P}$ & Coefficients & $\begin{array}{l}\mathrm{F} \\
(\text { d.f. }=1,10)\end{array}$ & $\mathrm{P}$ \\
\hline Intercept & $0.191 \pm 0.023$ & 69.846 & $<0.0001$ & $0.131 \pm 0.026$ & 25.610 & 0.0005 \\
\hline $\begin{array}{l}\text { Winter } \\
\text { Rain }\end{array}$ & $0.0004 \pm 0.0008$ & 0.206 & 0.660 & $0.001 \pm 0.0009$ & 1.29479 & 0.282 \\
\hline Intercept & $0.163 \pm 0.024$ & 47.073 & $<0.0001$ & $0.102 \pm 0.027$ & 14.663 & 0.0033 \\
\hline $\begin{array}{l}\text { Annual } \\
\text { Rain }\end{array}$ & $0.0007 \pm 0.0003$ & 3.813 & 0.0794 & $0.0009 \pm 0.0004$ & 5.413 & 0.0422 \\
\hline
\end{tabular}


Figure 2.4 Comparison of total plant cover on bird and non - bird islands from 1996 - 2015. Plant cover data were averaged for each island and arcsin square root transformed. Plant cover data were then averaged for each island status (i.e., bird and non - bird). 


\subsubsection{Tenebrionid Abundance}

Mean tenebrionid abundance was significantly higher on bird islands than non - bird islands through the study period $(t=5.0594, \mathrm{P}<0.0001$, d.f. $=19 ; t$ test for paired comparisons). On the whole, tenebrionid beetles were six times more abundant on seabird islands, and only in 2006 and 2012 were tenebrionid abundances lower or similar in seabird islands than in non - bird islands. In contrast, in 1998, 2015 and 2016, the abundances on seabird islands were 10 to 40 times higher than on non - bird islands, with abundances correlating with two of the strongest El Niño events $(1998,2016)$ in the past two decades (Wolter and Timlin 1998). Tenebrionid variance was significantly higher on bird islands (2.19 $\pm 0.24)$ than non - bird islands $(1.29 \pm 0.12, t=3.48, \mathrm{P}=0.001$, d.f. $=14$, twotailed $t$ test). 
Figure 2.5 Comparison of tenebrionid abundances on bird and non - bird islands with winter precipitation. Total tenebrionid species abundance data were averaged for each pitfall trap per island. The tenebrionid averages were then square root transformed and averaged for each island status group (i.e., bird and non- bird). 


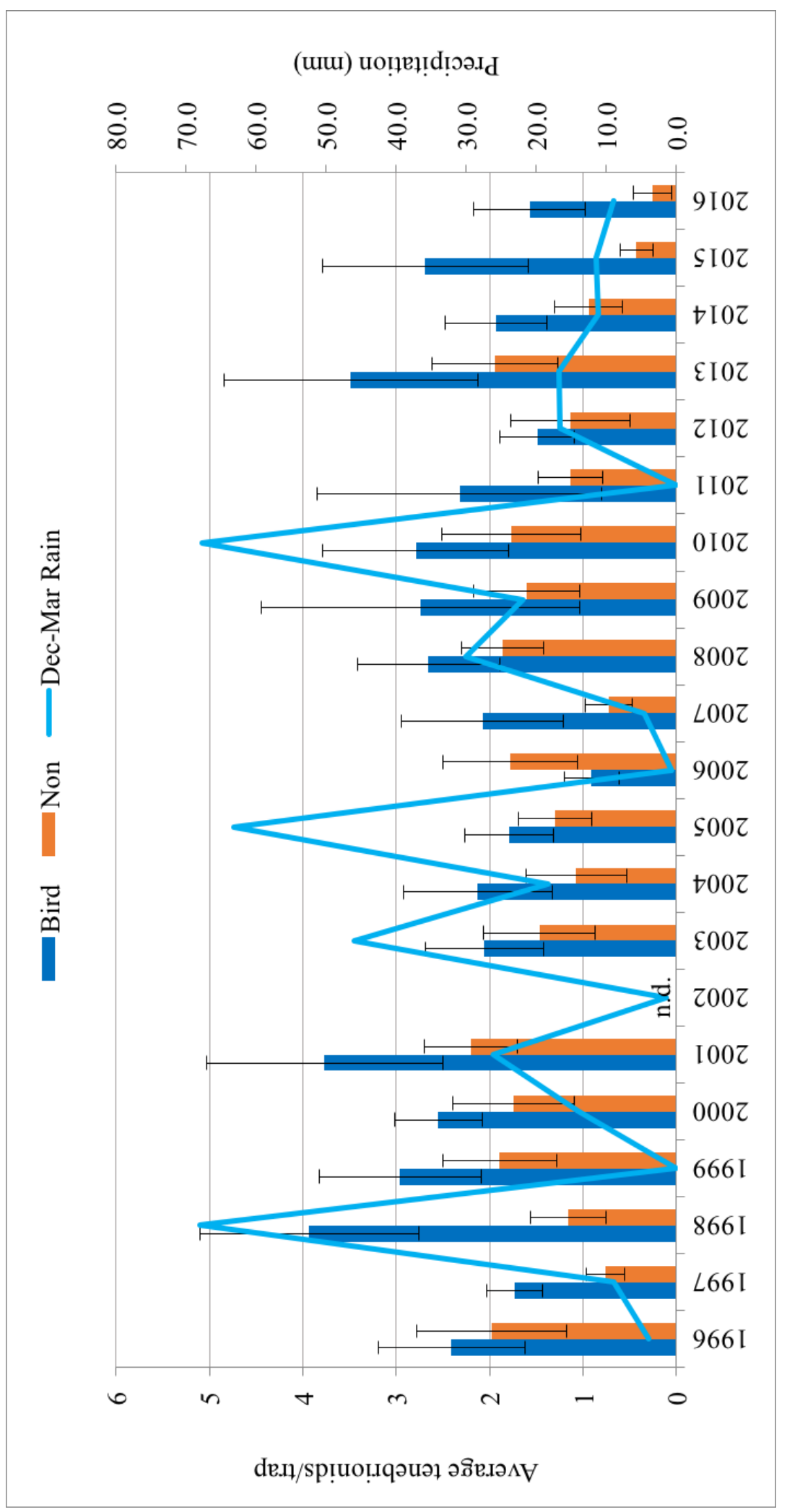


Average tenebrionid abundance was not related to winter precipitation for bird islands (Table 2.3). Regressions were run for a one - year lag in winter rain in which there were no significances for bird and non - bird islands (Table 2.3). Regressions were also run for a two - year lag in winter rain, with no significances after Bonferroni corrections were made for bird and non - bird islands (Table 2.3). 
Table 2.3 Univariate results from a multivariate GLM regression (sigma restricted parameterization) for the relationship between rain (winter and annual) and tenebrionid abundance (square root transformed) on non - bird and bird islands for present year, one - year lagged response and two - years lagged response. 


\begin{tabular}{|c|c|c|c|c|c|c|}
\hline \multirow[b]{2}{*}{ Effect } & \multicolumn{3}{|l|}{ Non-bird } & \multicolumn{3}{|c|}{ Bird } \\
\hline & Coefficients & $\begin{array}{l}\mathrm{F} \\
(\mathrm{d} . \mathrm{f} .=1,16)\end{array}$ & $\mathrm{P}$ & Coefficients & $\begin{array}{l}\mathrm{F} \\
(\text { d.f. }=1,16)\end{array}$ & $\mathrm{P}$ \\
\hline Intercept & $1.120 \pm 0.320$ & 12.245 & 0.0030 & $2.702 \pm 0.418$ & 41.785 & $<0.0001$ \\
\hline $\begin{array}{l}\text { Winter } \\
\text { Rain }\end{array}$ & $0.007 \pm 0.006$ & 1.202 & 0.2892 & $0.008 \pm 0.008$ & 0.935 & 0.3481 \\
\hline Rain 1 yr lag & $0.008 \pm 0.005$ & 2.277 & $\begin{array}{l}0.1508 \\
0.4478\end{array}$ & $-0.004 \pm 0.007$ & $\begin{array}{l}0.327 \\
4.929\end{array}$ & $\begin{array}{l}0.5755 \\
0.0412\end{array}$ \\
\hline Rain 2 yr lag & $-0.004 \pm 0.005$ & 0.606 & 0.4478 & $-0.014 \pm 0.006$ & 4.929 & 0.0412 \\
\hline Intercept & $1.816 \pm 0.432$ & 17.654 & 0.0007 & $2.798 \pm 0.559$ & 25.046 & 0.0001 \\
\hline $\begin{array}{l}\text { Annual } \\
\text { Rain }\end{array}$ & $-0.005 \pm 0.004$ & 1.676 & 0.2138 & $0.004 \pm 0.005$ & 0.769 & 0.3935 \\
\hline Rain 1 yr lag & $-0.0003 \pm 0.0004$ & 0.007 & 0.9355 & $-0.005 \pm 0.005$ & 1.035 & 0.3242 \\
\hline Rain 2 yr lag & $-0.004 \pm 0.004$ & 1.328 & 0.2662 & $-0.008 \pm 0.005$ & 2.938 & 0.1058 \\
\hline
\end{tabular}




\subsubsection{Tenebrionid Diversity}

Diversity $\left(\mathrm{D}_{\mathrm{s}}\right)$ was variable among bird and non - bird islands (Figure 2.6). In $2007 \mathrm{D}_{\mathrm{s}}$ was significantly higher on bird islands $(\mathrm{F}=5.36, \mathrm{P}=0.05$, d.f. $=1,8$; One - way ANOVA) and coincided with the 2007 El Niño. All tenebrionids were separated into individual species and One - way ANOVAS were performed on square root +1 transformed average abundances on bird and non - bird islands. Triphalopsis californicus abundances were significantly higher on bird islands in $1997(\mathrm{~F}=5.03, \mathrm{P}=0.04$, d.f. $=1$, 12; One - way ANOVA). Argoporis apicalis were significantly higher on bird islands in $2005(\mathrm{~F}=8.25, \mathrm{P}=0.01$, d.f. $=1,12$; One - way ANOVA) and in $2013(\mathrm{~F}=4.67, \mathrm{P}=0.05$, d.f. $=1,12$; One - way ANOVA). 
Figure 2.6 Comparison of tenebrionid diversity on bird and non - bird islands from 1996 - 2016. The average Simpson Diversity were averaged for each island group and arcsin square root transformed. There is no error bar for non - bird islands in 2016 since $D_{s}$ could only be determined for one island due to low numbers of spp. found on non - bird islands. 


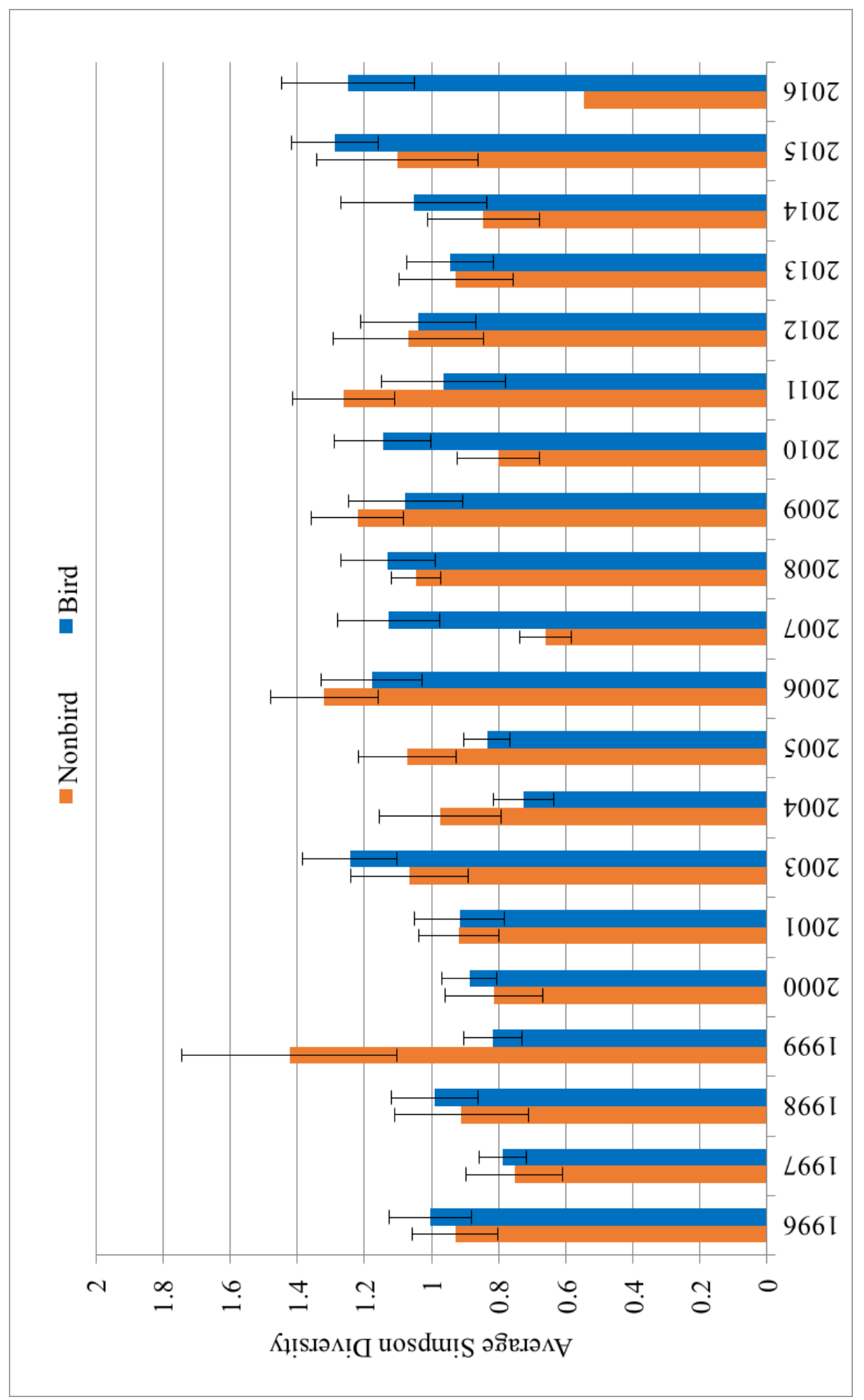




\subsubsection{Tenebrionid Community Composition}

Using NMDS we looked at the tenebrionid communities across islands and there were no clear trends in community composition. However, Analysis of Similarity (ANOSIM) results indicated that during the moderate El Niño event of 2005 there was a significant difference in tenebrionid assemblage composition on bird islands $(\mathrm{R}=0.21, \mathrm{P}=0.01)$ than non - bird islands. Although a moderate $\mathrm{El}$ Niño event, precipitation in 2005 (63.2mm of rain) was close to the strong El Niño event in 1998 (68 mm of rain). To determine which species contributed to these differences, similarity percentage analysis (SIMPER) were performed on each island for each year. In 2005, Microschattia championi and Triphalopsis californicus were the dominant tenebrionids on non - bird islands while Argoporis apicalis and Triphalopsis californicus were the dominant tenebrionids on bird islands (Table 2.4). None of the remaining 19 years were significantly different ( $\mathrm{P}$ $>0.10)$. 
Table 2.4 Average abundance of dominant tenebrionids on non - bird islands and bird islands in 2005 (87.9 \% average dissimilarity; SIMPER). 


\begin{tabular}{|l|l|l|}
\hline Species & Non - bird islands & Bird Islands \\
\hline Microschattia championi & $0.17 \pm 0.14$ & $0.14 \pm 0.14$ \\
\hline Triphalopsis californicus & $0.70 \pm 0.52$ & $0.25 \pm 0.15$ \\
\hline Argoporis aplicalis & $0.01 \pm 0.01$ & $2.38 \pm 1.01$ \\
\hline
\end{tabular}




\subsubsection{Tenebrionid Community Composition with Environmental Variables}

Canonical Correspondence Analysis (CCA) was performed on square root transformed tenebrionid abundances with environmental variables as potential drivers of abundance (Figure 2.7). Environmental factors included winter rainfall, soil moisture content, guano cover, and plant cover of each island. The arrow length denotes the importance of each environmental variable, with the direction showing how well the environment is correlated with the different species composition axes. Additionally, the angle between the arrows indicates correlations between the environmental variables. The tenebrionid species' location relative to the arrows signifies their environmental preferences. The total variation was 4.12 and the environmental variables accounted for $10.4 \%$ of the variation in tenebrionid community composition ( $p$ seudo $-\mathrm{F}=3.8, \mathrm{P}=0.002$ ). 
Figure 2.7 Canonical Correspondence Analysis (CCA) of tenebrionid spp. abundances (square root transformed) and environmental variables. 


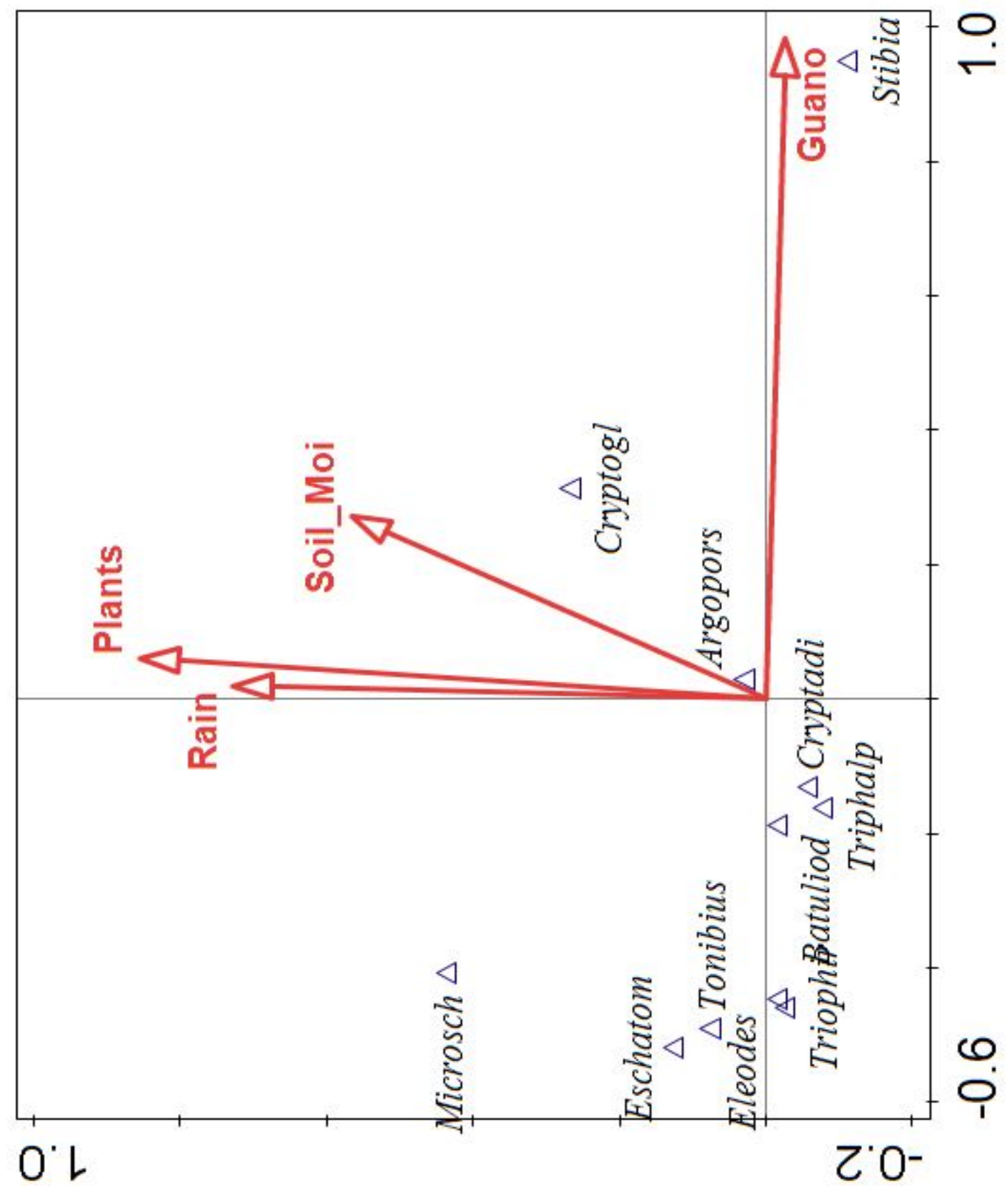




\subsection{Discussion}

\subsubsection{Effects of Precipitation}

On the western coast of the Americas, El Niño events often bring large storms, leading to an increase in precipitation (Goldberg et al. 1987). For Bahía de los Ángeles, when El Niños events bring heavy rain can switch a system dependent on donor - controlled subsidies such as marine input, to a system dependent on in - situ productivity due to increased production and subsequent detrital pools (Polis et al. 1997b). Polis and others suggest that pulsed inputs of terrestrial productivity are long- lasting changes that affect ecosystems after the E1 Niño event has passed (Polis et al. 1997b, Stapp et al. 1999, Holmgren and Scheffer 2001). Heavy rains alter desert food web dynamics by switching a system dependent on allochthonous input to a system dependent on in - situ terrestrial productivity (Figure 2.8)(Polis et al. 1997b). 
Figure 2.8 Food web of terrestrial communities on the archipelago of Bahía de los Ángeles. Top diagram (a) indicates a normal arid year in which communities are supported by allochtonous productivity. Bottom diagram (b) indicates a wet year in which communities are supported by in - situ terrestrial productivity (redrawn from Polis et al. 1997b). 

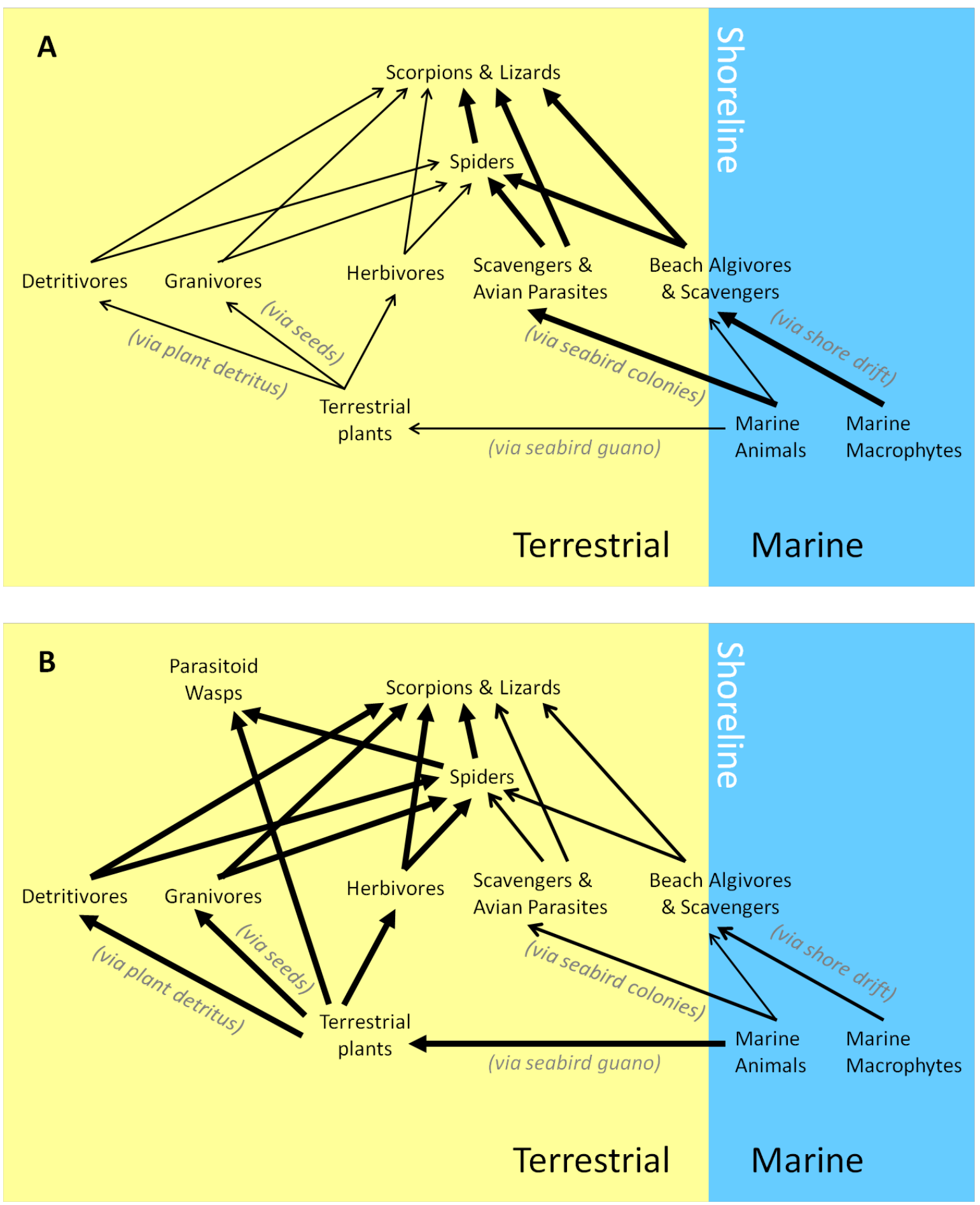
In periods of heavy rain, guano that is rich in Nitrogen and Phosphorous is mobilized, fertilizing plants and increasing primary productivity (Anderson and Polis 1999). Due to the importance of winter rain on vegetation dynamics for this location, we expected plant cover to increase in years with heavy rain, particularly on bird islands due to the beneficial interaction between guano and rain (Polis et al. 1997b). Although winter rain was considered by Polis and colleagues in previous work (Polis et al. 1997b) since it brings non - torrential, ground - penetrating rains that are beneficial for plant growth in this area (Dice 1939, Crosswhite and Crosswhite 1982), we saw no statistically significant relationships between winter precipitation and average plant cover on bird or non - bird islands. We also did not see any relationships between plant growth and rain using annual rain calculations.

This may be due to the method of vegetation analysis used (i.e., total plant cover); different relationships may have been observed if analyses were carried out for annual and perennial plants separately. Bird and non - bird islands differ in the cover of both types of plants (Sánchez - Piñero and Polis 2000) and their responses to precipitation may be different. Furthermore, the islands of Bahía de los Ángeles are very heterogeneous and there probably exists a high error term associated with individual changes in plant cover on the islands. 


\subsubsection{Vegetation}

Plant growth was posited to be particularly strong on bird islands during El Niño events that bring heavy precipitation (Stapp et al. 1999). This was true for the El Niño event in 1997 - 1998 that was included in their study, but does not seem to be a general rule when extending the dataset to 2016. For the 12 years that plant cover was assessed, plant cover was higher on non - bird islands except during the El Niño of 1998 (Figure 2). Out of these 12 years of plant cover assessment, three El Niño events were captured (1998, 2005, and 2007). 2006 and 2007 were two dry years in a row (winter precipitation; figure 2.3), however we do not know how plants recovered after that as sampling was not conducted the following years. The lower plant cover on bird islands in comparison to non - bird islands may be explained by trampling and harvesting of seabirds, as well as water evaporation from the soil and large amounts of dried guano, creating toxic soil conditions inhibiting plant growth (Sanchez-Pinero and Polis 2000, Ellis 2005). In addition, there was no significant difference in plant variability on bird or non - bird islands. This may be explained by the fact that perennials are more abundant on non - bird islands, whereas annuals are dominant on bird islands, and thus differences may have been obscured by our analysis including only total plant cover.

Our 20 - year dataset included two strong El Niños events. While winter precipitation in 1998 brought $68 \mathrm{~mm}$ of rain, winter precipitation in 2016, the strongest El Niño event to occur since 1998 (MEI Index; Wolter and Timlin 1998), delivered only $9 \mathrm{~mm}$ of rain. In comparison, the moderate El Niño in 2005 brought an amount of rain comparable to that of the strong El Niño in 1998 (63.2 mm). 
Although rainfall was similar, overall plant cover in 2005 was less than half the overall amount of plant cover in 1998. Not all El Niño events bring heavy precipitation, and examination of our more complete dataset makes it difficult to support the claim that El Niño events alone cause the changes in terrestrial communities in the archipelago of Bahía de los Ángeles seen in this and other studies.

\subsubsection{Tenebrionid Abundance}

On bird islands, seabird products influence tenebrionid abundance through nutrient rich guano which increases primary production and through carrion and fish scraps which allow tenebrionids to increase despite decreased plant growth when seabird density is very high (Sánchez - Piñero and Polis 2000). These added but inconsistent resources of marine input likely explains the almost two times higher tenebrionid variance through time on bird islands $(2.19 \pm 0.24)$ than on non - bird islands (1.29 \pm 0.12$)$.

Although bird islands have added resources from seabird influence, there were no significance differences in tenebrionoid abundances between bird and non - bird islands for the entire 20 years (which incorporated five El Niño events; 2016 El Niño event being comparable in strength to 1998 El Niño event) (Figure 2.1). This may be explained in part because El Niño events do not always bring heavy precipitation (best illustrated by the 2015 - 2016 event). There were also no relationships between winter rain and tenebrionid abundance on both island groups, likely explained by tenebrionid lifecycles, as larval development can last one or 
more years and a lagged response to a pulse in resources may be expected (Knor 1975, De Los Santos et al. 1988). Larvae are also able to shorten or lengthen their development depending on environmental conditions and resources (Howe 1962, Smith and Barker 1991). Consequently, differences in lagged responses to precipitation could be due to differences in the life histories of tenebrionids living on islands with different resource availability.

\subsubsection{Tenebrionid Diversity}

Tenebrionid diversity varied throughout 1996 - 2016 among island groups (Figure 2.4) with no significant differences in diversity between bird and non - bird islands. Although there were six El Niño events captured in our dataset, none of the years correlated with diversity. These findings continue to oppose the claim that El Niño events may be the main determinant in changes in terrestrial communities in the archipelago of Bahía de los Ángeles.

\subsubsection{Tenebrionid Community Composition}

Finding few differences in tenebrionid community structure using simple, univariate techniques, we turned to more sensitive statistical methods, and still found few differences. NMDS showed no significant changes in community structure across islands $(\mathrm{P}>0.1)$. Again, tenebrionids did not show a consistent trend in response to El Niño events both looking across individual years and at the community level. 
Environmental influences explained $10.4 \%$ of variation in tenebrionid community composition (Figure 2.5) indicating that there are other drivers influencing tenebrionid communities, however few differences were observed when looking at the relationship between assemblage composition and environmental variables. This may be due to many indirect effects and lagged responses from a detrital based system which is not as simple of a relationship when using a long time scale as opposed to a short time scale as used in previous studies (Polis and Hurd 1996, Polis et al. 1997b, Anderson and Polis 1999). 


\section{CHAPTER 3}

\subsection{CONCLUSION}

Signals are difficult to observe in detrital - based systems due to variability in detrital size, decomposition rate, nutritional content, etc. as well as top - down pressures (Hagen et al. 2012). The results from this study show that the effects on community structure change under different rain regimes. Although precipitation increases terrestrial in - situ productivity, which in turn explains a large amount of the variance in abundance of tenebrionids, the insular ecosystems of Bahía de los Ángeles are extremely complicated with many other contributing factors.

While some species (e.g., web - building spiders) in this archipelago may respond immediately to changes in precipitation regime, other species (e.g., detritivorous arthropods) may display a muted or lagged response, mediated by the availability of marine input or other species interactions. These relationships are neither simple nor discrete, and time scales, natural history of organisms, and the structure of their food webs need to be considered when looking at influences in community structure to better understand the long - term and indirect effects of spatial subsidies. 


\subsection{REFERENCES}

Anderson, W. B., and G. A. Polis. 1999. Nutrient fluxes from water to land: seabirds affect plant nutrient status on Gulf of California islands. Oecologia 118:324-332.

Anderson, W. B., D. A. Wait, and P. Stapp. 2008. Resources from another place and time: Responses to pulses in a spatially subsidized system. Ecology 89:660- 670 .

Carlo, E. 1936. Bonferroni. 1936. Teoria statistica delle classi e calcolo delle probabilità. Pubblicazioni del Regio Istituto Superiore di Scienze Economiche e Commerciali di Firenze 8.

Christensen, R. 1987. One-Way ANOVA. Pages 57-69 Plane Answers to Complex Questions. Springer.

Clarke, K. R., and R. N. Gorley. 2006. PRIMER V6: user manual-tutorial. Plymouth Marine Laboratory.

Cottam, G., and J. T. Curtis. 1956. The Use of Distance Measures in Phytosociological Sampling. Ecology 37:451- 460.

Connell, J. H. 1978. Diversity in tropical rain forests and coral reefs. Science 199:1302-1310.

Crosswhite, F. S., and C. D. Crosswhite. 1982. The Sonoran Desert. Reference Handbook on the Deserts of North America:163- 295.

De Los Santos, A., C. Montes, and L. R. Diaz. 1988. Life histories of some darkling beetles (Coleoptera: Tenebrionidae) in two Mediterranean ecosystems in the lower Guadalquivir (Southwest Spain). Environmental Entomology 17:799- 814.

Dice, L. R. 1939. The Sonoran biotic province. Ecology 20:118- 129.

Doblas-Miranda, E., F. Sánchez-Piñero, and A. González-Megías. 2009. Different microhabitats affect soil macroinvertebrate assemblages in a Mediterranean arid ecosystem. Applied Soil Ecology 41:329-335.

Ellis, J. C. 2005. Marine Birds on Land: A Review of Plant Biomass, Species Richness, and Community Composition in Seabird Colonies. Plant Ecology 181:227-241. 
Everett, W. T., and D. W. Anderson. 1991. Status and conservation of the breeding seabirds on offshore Pacific islands of Baja California and the Gulf of California. Seabird Status and Conservation: A Supplement. International Council for Bird Preservation, Cambridge:115- 139.

Goldberg, R., M. Tisnado, and R. Scofield. 1987. Characteristics of extreme rainfall events in Northwestern Peru during the 1982-1983 El Niño period. Journal of Geophysical Research: Oceans 92:14225-14241.

Hagen, E. M., K. E. McCluney, K. A. Wyant, C. U. Soykan, A. C. Keller, K. C. Luttermoser, E. J. Holmes, J. C. Moore, and J. L. Sabo. 2012. A metaanalysis of the effects of detritus on primary producers and consumers in marine, freshwater, and terrestrial ecosystems. Oikos 121:1507-1515.

Holmgren, M., and M. Scheffer. 2001. El Niño as a window of opportunity for the restoration of degraded arid ecosystems. Ecosystems 4:151- 159.

Holton, J. R., and R. Dmowska. 1989. El Niño, La Niña, and the southern oscillation. Academic press.

Howe, R. 1962. The effect of temperature and relative humidity on the rate of development and the mortality of Tribolium madens (Charp.)(Coleoptera, Tenebrionidae). Annals of Applied Biology 50:649-660.

Knor, N. 1975. Life cycles of darkling beetles (Coleoptera, Tenebrionidae) of Tuva. Soviet journal of ecology.

Levin, L. A., D. F. Boesch, A. Covich, C. Dahm, C. Erseus, K. C. Ewel, R. T. Kneib, A. Moldenke, M. A. Palmer, P. Snelgrove, D. Strayer, and J. M. Weslawski. 2001. The function of marine critical transition zones and the importance of sediment biodiversity. Ecosystems 4:430-451.

Magurran, A. E. 2013. Ecological diversity and its measurement. Springer Science \& Business Media.

Ostfeld, R. S., and F. Keesing. 2000. Pulsed resources and community dynamics of consumers in terrestrial ecosystems. Trends in Ecology \& Evolution 15:232-237.

Palmer, M. W. 1993. Putting things in even better order: the advantages of canonical correspondence analysis. Ecology 74:2215-2230.

Polis, G. A., W. B. Anderson, and R. D. Holt. 1997a. Toward an integration of landscape and food web ecology: The dynamics of spatially subsidized food webs. Annual Review of Ecology and Systematics 28:289-316. 
Polis, G. A., and S. D. Hurd. 1996. Linking Marine and Terrestrial Food Webs: Allochthonous Input from the Ocean Supports High Secondary Productivity on Small Islands and Coastal Land Communities. The American Naturalist 147:396-423.

Polis, G. A., S. D. Hurd, C. T. Jackson, and F. S. Pinero. 1997b. El Nino effects on the dynamics and control of an island ecosystem in the Gulf of California. Ecology 78:1884-1897.

Polis, G. A., M. E. Power, and G. R. Huxel. 2004. Food webs at the landscape level. University of Chicago Press.

Rodríguez, S. R. 2003. Consumption of drift kelp by intertidal populations of the sea urchin Tetrapygus niger on the central Chilean coast: possible consequences at different ecological levels. Marine Ecology Progress Series 251:141-151.

Sánchez - Piñero, F., and G. A. Polis. 2000. Bottom-up dynamics of allochthonous input: Direct and indirect effects of seabirds on islands. Ecology 81:3117-3132.

Sheffield, J., and E. F. Wood. 2008. Global trends and variability in soil moisture and drought characteristics, 1950-2000, from observation-driven simulations of the terrestrial hydrologic cycle. Journal of Climate 21:432458.

Simpson, E. H. 1949. Measurement of diversity. Nature.

Šmilauer, P., and J. Lepš. 2014. Multivariate analysis of ecological data using CANOCO 5. Cambridge university press.

Smith, L., and P. Barker. 1991. Effect of temperature on the development, oviposition, and mortality of Tribolium audax Halstead and Tribolium madens (Charpentier)(Coleoptera: Tenebrionidae). Canadian journal of zoology 69:1189-1193.

Sokal, R., and F. Rolf. 1995. Biometry: the principals and practice of statistics in biology research WF Freeman. New York.

Stapp, P., G. A. Polis, and F. S. Piñero. 1999. Stable isotopes reveal strong marine and El Niño effects on island food webs. Nature 401:467-469.

Turner, F. B., and D. C. Randall. 1989. Net production by shrubs and winter annuals in southern Nevada. Journal of Arid Environments 17:23-36. 
Velarde, E., and D. W. Anderson. 1994. Conservation and management of seabird islands in the Gulf of California: setbacks and successes. Seabirds on islands: threats, case studies and action plans:229-243.

Vetter, E. W. 1995. Detritus-based patches of high secondary production in the nearshore benthos. Marine Ecology Progress Series:251-262.

Wolter, K., and M. S. Timlin. 1998. Measuring the strength of ENSO events: how does 1997/98 rank? Weather 53:315-324.

Xia, Y., M. B. Ek, Y. Wu, T. Ford, and S. M. Quiring. 2015a. Comparison of NLDAS-2 simulated and NASMD observed daily soil moisture. Part I: Comparison and analysis. Journal of Hydrometeorology 16:1962-1980.

Xia, Y., M. B. Ek, Y. Wu, T. Ford, and S. M. Quiring. 2015b. Comparison of NLDAS-2 simulated and NASMD observed daily soil moisture. Part II: Impact of soil texture classification and vegetation type mismatches. Journal of Hydrometeorology 16:1981-2000.

Zimmerman, D. W., and B. D. Zumbo. 1993. Rank transformations and the power of the Student $t$ test and Welch t'test for non-normal populations with unequal variances. Canadian Journal of Experimental Psychology/Revue canadienne de psychologie expérimentale 47:523. 


\section{Appendices}

Appendix A

Average Monthly Precipitation Data from 1996- 2016

\begin{tabular}{|l|l|l|l|l|l|l|l|l|l|l|l|l|}
\hline YEAR & JAN & FEB & MAR & APR & MAY & JUN & JUL & AUG & SEP & OCT & NOV & DEC \\
\hline 1995 & 15.0 & 12.0 & 1.0 & 0.0 & 0.0 & 0.0 & 0.0 & 0.0 & 0.0 & 0.0 & 0.0 & 0.0 \\
\hline 1996 & 0.0 & 4.0 & 0.0 & 0.0 & 0.0 & 0.0 & 0.0 & 0.0 & 0.0 & 20.0 & 0.0 & 0.0 \\
\hline 1997 & 1.0 & 8.0 & 0.0 & 4.0 & 0.0 & 0.0 & 0.0 & 0.0 & 58.0 & 0.0 & 5.0 & 35.0 \\
\hline 1998 & 0.0 & 27.0 & 6.0 & 0.0 & 0.0 & 0.0 & 16.0 & 0.0 & 0.0 & 0.0 & 0.0 & 0.0 \\
\hline 1999 & 0.0 & 0.0 & 0.0 & 0.0 & 0.0 & 0.0 & 0.0 & 0.0 & 0.0 & 0.0 & 0.0 & 0.0 \\
\hline 2000 & 0.0 & 0.0 & 14.0 & 0.0 & 0.0 & 0.0 & 2.0 & 1.0 & 3.0 & 12.0 & 6.5 & 0.0 \\
\hline 2001 & 12.7 & 6.0 & 7.5 & 18.0 & 0.0 & 0.0 & 0.0 & 0.0 & 7.0 & 3.0 & 0.0 & 0.0 \\
\hline 2002 & 0.5 & 0 & 1.01 & 0.25 & 0 & 0 & 0 & 0 & 0 & 0.25 & 8.34 & 9.33 \\
\hline 2003 & 0.5 & 34.23 & 2.02 & 0 & 0 & 0 & 0 & 6.32 & 22.13 & 4.79 & 6.78 & 7.3 \\
\hline 2004 & 11.0 & 0.0 & 0.0 & 0.0 & 0.0 & 0.0 & 0.0 & 0.0 & 19.0 & 0.0 & 37.0 & 17.5 \\
\hline 2005 & 20.68 & 22.23 & 2.77 & 1.52 & 0 & 0.25 & 0 & 4.83 & 0 & 0.5 & 2.01 & 0 \\
\hline 2006 & 0 & 0.5 & 0.25 & 0 & 0 & 0 & 0 & 0 & 41.85 & 43.39 & 0 & 3.05 \\
\hline 2007 & 1.51 & 0 & 0 & 0 & 0 & 0 & 0 & 0.75 & 0 & 0.25 & 9.1 & 29.85 \\
\hline 2008 & 0.25 & 0 & 0 & 0 & 0 & 14.22 & 0.25 & 5.07 & 0 & 0 & 1.01 & 2.02 \\
\hline 2009 & 10.1 & 9.89 & 0 & 0.5 & 0 & 2.53 & 0 & 0 & 0 & 0.25 & 2.02 & 2.54 \\
\hline 2010 & 50.5 & 12.2 & 2.5 & 0.0 & 0.0 & 0.0 & 0.0 & 0.0 & 0.0 & 0.0 & 0.0 & NA \\
\hline 2011 & 0 & 0 & 0 & 2.51 & 0 & 0 & 0 & 0 & 0 & 0 & 0 & 6.1 \\
\hline 2012 & 0.0 & 10.2 & 0.3 & 0.0 & 0.0 & 0.3 & 0.0 & 21.6 & 12.7 & 1.3 & 0.0 & 9.1 \\
\hline 2013 & 7.4 & 0.3 & 0.0 & 0.0 & 0.0 & 0.3 & 3.1 & 12.7 & 0.0 & 0.0 & 14.0 & 2.5 \\
\hline 2014 & 0.3 & 0.0 & 8.4 & 0.0 & 0.0 & 0.0 & 0.0 & 0.0 & 40.0 & 8.1 & 0.0 & 2.8 \\
\hline 2015 & 4.1 & 0.8 & 3.8 & 0.0 & 0.0 & 33 & 7.1 & 0.5 & 24.9 & 0.8 & 2.8 & 0.3 \\
\hline 2016 & 7.4 & 0.0 & 1.3 & 2.0 & 0.3 & 0.0 & 3.0 & 0.0 & 1.0 & 0.3 & 0.0 & 19.3 \\
\hline & & & & & & & & & & & \\
\hline
\end{tabular}




\section{Appendix B}

Average Monthly Temperature $\left(\mathrm{C}^{\circ}\right)$ Data from 1996 - 2012

\begin{tabular}{|l|l|l|l|l|l|l|l|l|l|l|l|l|}
\hline YEAR & JAN & FEB & MAR & APR & MAY & JUN & JUL & AUG & SEP & OCT & NOV & DEC \\
\hline 1996 & 17.3 & 17.6 & 19.6 & 22.3 & 25.5 & 29.5 & 30.8 & 30.7 & 27.7 & 23.7 & 19.3 & 16.1 \\
\hline 1997 & 15.4 & 15.0 & 18.3 & 19.7 & 25.2 & 29.5 & 33.6 & 31.9 & 30.8 & 24.1 & 19.9 & 15.7 \\
\hline 1998 & 15.7 & 15.7 & 16.7 & 18.6 & 22.6 & 26.6 & 29.9 & 30.2 & 28.9 & 23.1 & NA & NA \\
\hline 1999 & 15.5 & 15.1 & 15.9 & 17.9 & 22.6 & 26.2 & 29.1 & 29.2 & 29.0 & 25.6 & 19.7 & 15.2 \\
\hline 2000 & 14.8 & 16.0 & 16.6 & 21.3 & 23.1 & 26.8 & 29.8 & 29.6 & 28.8 & 22.6 & 16.8 & 15.3 \\
\hline 2001 & 13.5 & 13.5 & 16.2 & 18.7 & 23.8 & 27.1 & 29.9 & 30.7 & 29.4 & 24.3 & 20.8 & 14.7 \\
\hline 2002 & 13.7 & 15.0 & 15.9 & 19.0 & 24.1 & 26.8 & 28.8 & 29.0 & 30.0 & 22.4 & 19.1 & 14.9 \\
\hline 2003 & 16.1 & 15.9 & 17.6 & 18.9 & 22.8 & 25.8 & 28.8 & 29.7 & 30.0 & 22.5 & 19.1 & 14.9 \\
\hline 2004 & 13.3 & 13.4 & 18.4 & 19.1 & 23.3 & 25.8 & 29.6 & 30.1 & 27.5 & 22.3 & 17.1 & 14.8 \\
\hline 2005 & 14.1 & 14.6 & 17.4 & 19.6 & 21.6 & 26.5 & 30.5 & 29.7 & 29.4 & 23.5 & 19.7 & 15.0 \\
\hline 2006 & 13.9 & 14.7 & 15.4 & 18.7 & 21.9 & 28.3 & 30.3 & 30.1 & 27.6 & 23.6 & 19.3 & 15.1 \\
\hline 2007 & 12.3 & 15.0 & 18.5 & 19.4 & 23.5 & 27.4 & 29.2 & 30.1 & 28.4 & 23.7 & 18.9 & NA \\
\hline 2009 & 14.3 & 14.5 & 18.4 & 20.8 & 24.2 & 26.7 & 30.6 & 31.3 & 29.1 & 23.5 & 19.2 & 14.8 \\
\hline 2010 & 13.8 & 15.8 & 18.6 & 20.5 & 24.4 & 27.7 & 31.8 & 32.3 & 28.8 & 25.3 & 20.2 & 17.2 \\
\hline 2011 & 15.3 & 15.9 & 18.8 & 22.8 & 25.5 & 28.9 & 32.1 & 32.2 & 31.0 & 26.8 & 20.3 & 15.6 \\
\hline 2012 & 17.0 & 16.5 & 18.3 & 22.0 & 26.1 & 28.9 & 32.0 & 31.9 & 30.2 & 26.0 & 22.9 & NA \\
\hline
\end{tabular}




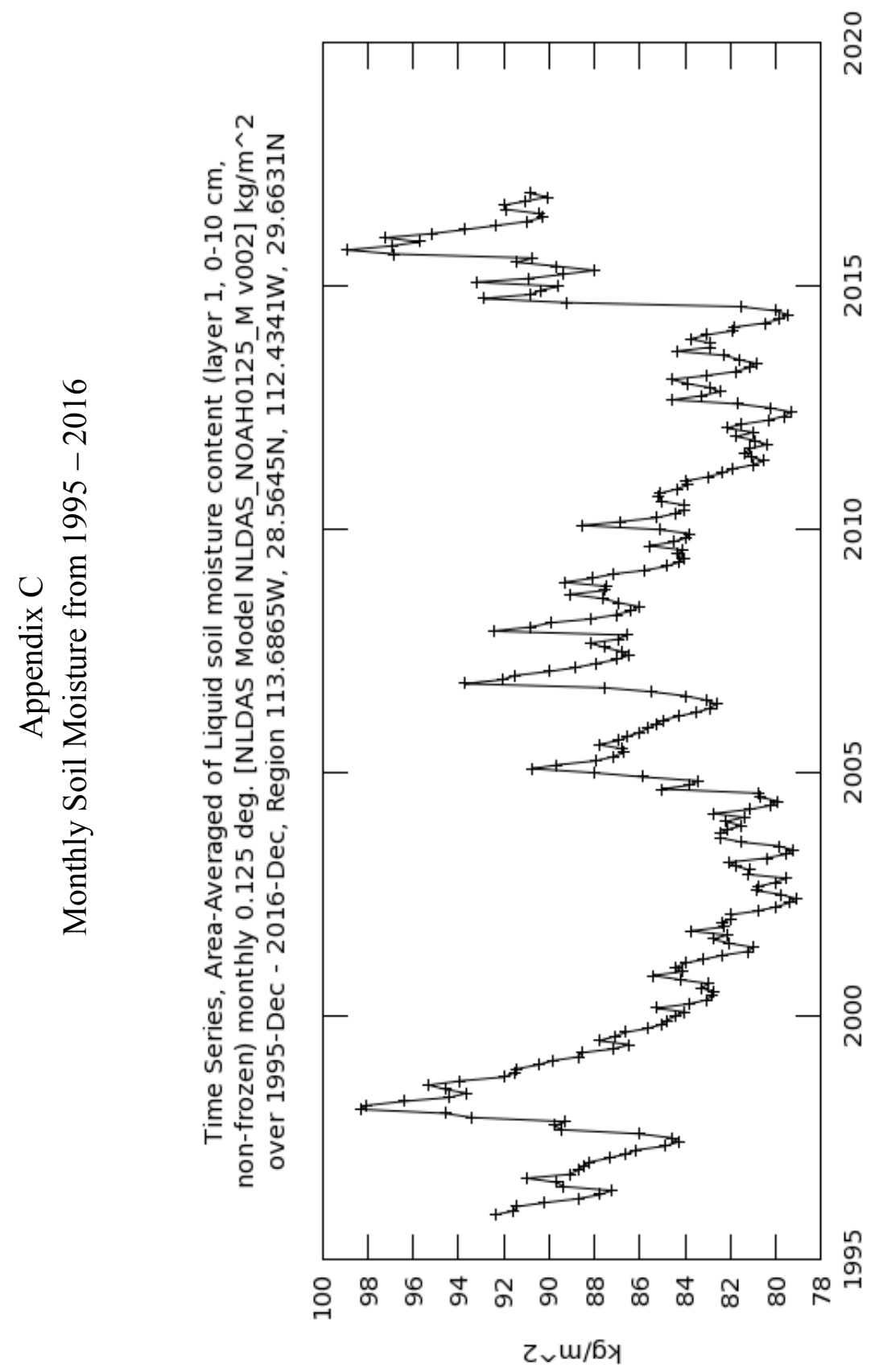

